Received Date : 25-Apr-2013

Revised Date : 31-Dec-2013

Accepted Date : 13-Mar-2014

Article type : Original Manuscript

\title{
Signatures of slope failures and river-delta collapses in a perialpine lake (Lake Lucerne, Switzerland)
}

Associate Editor - Nick Eyles

Running head: Slope failures and river-delta collapses, Lake Lucerne

Michael Hilbe ${ }^{1,2, *}$ and Flavio S. Anselmetti ${ }^{1,2}$

${ }^{1}$ Department of Surface Waters, Eawag, Swiss Federal Institute of Aquatic Science \& Technology, Überlandstrasse 133, 8600 Dübendorf, Switzerland

${ }^{2}$ Institute of Geological Sciences, University of Berne, Baltzerstrasse 1+3, 3012 Berne, Switzerland

*Corresponding author: michael.hilbe@geo.unibe.ch

\section{ABSTRACT}

Historical reports from the 17th Century document two destructive tsunamis with runups exceeding $5 \mathrm{~m}$, affecting proximal basins of Lake Lucerne (Switzerland). One event in AD 1601 is coeval with a strong nearby earthquake ( $\left.M_{w} c a 5.9\right)$, which caused extensive slope failures in many parts of the lake. The second event in AD 1687 is associated with an apparently spontaneous partial collapse of the Muota river delta. This study combines high-resolution bathymetry, reflection seismic and lithological data in order to document the sedimentary and morphological signatures of the two subaqueous mass movements that probably generated the observed tsunamis. Such mass movements are significant as a common sedimentation process and as natural hazard in fjord-type lakes and similar environments. The deposits, covering large parts of the basins with thicknesses reaching $>10 \mathrm{~m}$, consist of two subunits: A lower 'massflow deposit' contains variably deformed sediments from the source areas. Its emplacement affected pre-existing sediments, incorporating thin sediment slices into the deposit and increasing its volume. Deep-reaching deformation near This is an Accepted Article that has been peer-reviewed and approved for publication in the Sedimentology, but has yet to undergo copy-editing and proof correction. Please cite this article as an "Accepted Article"; doi: 10.1111/sed.12120

This article is protected by copyright. All rights reserved. 
basin margins is expressed as bulges on the lake floor. An overlying 'megaturbidite', featuring a graded, sandy base and a thick homogeneous muddy part, was deposited from suspended particles. The source area for the AD 1601 event, gently dipping lateral slopes with an unconsolidated hemipelagic sediment cover, hosts a pronounced slide scar with sharp escarpments and sliding surfaces. The source area for the AD 1687 event on an active delta slope has been overprinted by continued sedimentation and does not show an unambiguous scar. The case studies are exemplary for end-member types of source areas (lateral versus delta slopes) and trigger mechanisms (seismic versus aseismic); they show that morphological mapping and reconstructions of past events are key components of a hazard assessment for mass movement-generated tsunamis.

\section{KEYWORDS}

High-resolution bathymetry, lake sediments, natural hazards, subaqueous mass movements, tsunamis

\section{INTRODUCTION}

Over the past decades, investigations of the sea floor using survey methods such as reflection seismic profiling, sidescan sonar and multibeam echosounders, have revealed numerous signatures of subaqueous mass movements affecting sediments in many different settings from oceanic islands to continental margins (e.g. Hampton et al., 1996; Locat and Lee, 2002) and involving diverse processes ranging from slumping to turbidity currents (Mulder and Cochonat, 1996). It is widely understood that mass movements are one of the main processes that relocate sediments from slopes near the shores to the deep basins of water bodies, and it has been realized that mass movements may constitute a considerable natural hazard, either directly by damaging infrastructure along the coast or on the sea floor, but more importantly, by their potential to generate tsunamis (Masson et al., 2006; Ward, 2001). Although tsunamis generated by subaqueous slides are usually not as disastrous on a global scale as earthquake-generated ones, they can locally lead to severe damage and the loss of many lives, as illustrated for instance by the well-known historical events of Grand Banks in 1929 (Fine et al., 2005) and Papua New Guinea in 1998 (Tappin et al., 2008). Increasing awareness of these processes has intensified research on the topic, including analyses of slope stability (e.g. Sultan et al., 2004) or hazard assessments for landslide-generated tsunamis (e.g. McAdoo and Watts, 2004).

Similar to the oceans, geophysical and bathymetric surveys in lakes have shown that subaqueous mass movements are common in lacustrine environments (e.g. Gardner et al., 2000; Moernaut and De Batist, 2011; among many others). A group of lakes that exhibit abundant traces of mass movements are the perialpine lakes of Central Europe, situated along the northern and southern margins of the Alps and often reaching into the main Alpine valleys as elongated basins that have been shaped by glacial erosion during the Pleistocene (Finckh et al. 1984). These lakes, with deep and often narrow basins, gentle to steep lateral slopes and steep-fronted river deltas, are similar to fjords and particularly prone to slope failures (Hampton et al., 1996). Numerous recent to prehistoric events have been documented in these lakes (e.g. Siegenthaler et al., 1987; Chapron et al. 1996;

This article is protected by copyright. All rights reserved. 
among many others), and the fact that earthquake triggers are typical for these mass movements (although not the only ones, e.g. Girardclos et al., 2007), has been used to establish palaeoseismic reconstructions (e.g. Beck et al., 1996; Schnellmann et al., 2002; Strasser et al., 2006).

While even the largest mass movements observed in perialpine lakes are minor compared to the marine analogues, they can be huge in relation to the size of the small, constrained basins in which they occur. These events are often situated in densely populated areas, so that mass movements may constitute a considerable natural hazard. This assumption is supported by historical accounts that document large and destructive tsunami-type waves in these lakes (Siegenthaler and Sturm, 1991a; Kremer et al., 2012). Because the volume of the mass movements is one of the main influences controlling the height of the generated waves (Ward, 2001; Murty, 2003), areas with larger amounts of available sediment may potentially experience higher waves and/or shorter recurrence times. Any assessment of hazards related to subaqueous mass movements therefore benefits from accurate information on the deposits (lithology and geometry) and on the source areas of past events.

The present study revisits the sedimentary and morphological signatures of two major subaqueous mass movements in perialpine Lake Lucerne. These failures are apparently associated with two tsunamis that are among the highest known in history for perialpine lakes. Both mass movements occurred in basins with high sediment input by major rivers, and both are linked to the main tributaries, but the involved processes are probably different. By merging high-resolution bathymetry data with reflection seismic profiles and long piston cores from key locations, this study provides new comprehensive and quantitative basin-wide datasets that document source and depositional areas and allow determination of volumes and geometries of the failed sediments as well as of the deposits. The examination of the involved lithologies allows conclusions on processes governing the mass movements. These data provide a necessary basis for assessments of the hazard that such rare but high-impact events constitute for infrastructure, buildings and the population on the shores of perialpine lakes and similar basin settings.

\section{REGIONAL SETTING AND PREVIOUS WORK}

Lake Lucerne is a fjord-type perialpine lake situated on the northern margin of the Alps in Central Switzerland (Fig. 1). It covers a surface area of $114 \mathrm{~km}^{2}$ at a mean lake level of $433.6 \mathrm{~m}$ a.s.l. (metres above sea-level; BAFU, 2009), has a maximum depth of $214 \mathrm{~m}$ and is divided into seven basins separated by subaqueous sills (Hilbe et al., 2011). Three distal basins in the north-west are situated at the Alpine front; they are fed by local streams but do not have direct inflows of major rivers. The four proximal basins, in contrast, are located within major Alpine valleys and are fed by the four main tributary rivers that deliver $\mathrm{ca} 80 \%$ of the total water inflow to the lake (Fig. 1). The basins are carved into bedrock and have a fill of largely glacio-lacustrine deposits that reach a maximum thickness of $188 \mathrm{~m}$ in the Gersau basin (Finckh et al., 1984).

This article is protected by copyright. All rights reserved. 


\section{Sedimentation in the proximal basins}

In comparison to the distal basins, which are dominated by relatively low-rate hemipelagic sedimentation (Schnellmann et al., 2006; Strasser et al., 2007; Thevenon and Anselmetti, 2007), the proximal basins are characterized by a markedly different sedimentation regime largely influenced by clastic input. The three basins of this study (Gersau basin, $214 \mathrm{~m}$ maximum depth; Treib basin, 123 m; Lake Uri, 199 m; Fig. 1) have elongated shapes and often steep lateral slopes with typical slope angles from more than $30^{\circ}$ up to vertical. These lateral slopes are typically formed by bedrock with little to no sediment cover except for some steep-fronted, small lateral fan deltas and screeapron deltas (McPherson et al., 1987; Nemec, 1990), which are formed by small tributaries and ephemeral streams. The axial Gilbert-type deltas (Adams et al., 2001) are the main source of sediments to the basins and are formed by the main tributaries, the Reuss, Muota and Engelberger Aa rivers. These rivers drain mountainous catchments with sizes of several hundred square kilometres (see Fig. 1) and mean elevations between 1360 m (Muota) and 2010 m (Reuss; BAFU, 2009).

Sedimentation rates on the basin plains of the proximal basins are about one order of magnitude higher than the values reported for the distal basins, and even higher on parts of the delta slopes (Siegenthaler and Sturm, 1991a, b). The normal background sediment on the basin plains is laminated mud consisting of millimetre to centimetre-scale silt and clay layers with variable colours, as well as intercalated turbidites with thicknesses of up to several centimetres (Siegenthaler and Sturm, 1991b). These lithologies mainly reflect the varying conditions of the tributaries: Laminated mud is interpreted as a deposit from suspension clouds, while the larger turbidites are usually formed by underflows originating from the rivers, which occur during exceptional flood events with extreme sediment loads in the rivers (Siegenthaler and Sturm, 1991b).

\section{Holocene mass movements}

Within the regularly layered background sediments large mass-movement deposits are found. These deposits have been recognized in several basins of Lake Lucerne by Siegenthaler et al. (1987) as chaotic to transparent bodies in reflection seismic profiles, and as contorted and sheared to homogeneous sections in long sediment cores. The uppermost of these mass-movement deposits were tentatively linked to known historical earthquakes in the area, the $\mathrm{M}_{\mathrm{w}} c a 5.9$ Unterwalden earthquake in AD 1601 and the $M_{w} c a 5.7$ Altdorf earthquake in AD 1774 (Siegenthaler et al., 1987; Fäh et al., 2011). Schnellmann et al. (2002; 2006) systematically examined the sediments of the distal basins of Lake Lucerne with seismic-stratigraphic methods. These authors established a massmovement chronology and determined palaeoseismic events for the last 15000 years. Subsequent studies on the geotechnical properties of the failed sediments in the source areas (Strasser et al., 2007) and on the morphologies of the failure areas and the deposits (Hilbe et al., 2011) led to a detailed picture of the youngest mass movements in these basins.

The proximal basins have received less attention so far, although documented mass-movement deposits are much bigger in these basins. The high sedimentation rates and the thickness of the deposits complicate sediment subsurface imaging and sampling, thus only a few hundred years of

This article is protected by copyright. All rights reserved. 
event chronology can be reconstructed. Siegenthaler et al. (1987) identified a large mass-movement deposit in the Gersau basin related to the AD 1601 earthquake and defined a lower 'slump' of deformed and sheared layered mud deposited by the subaqueous mass movement and an overlying 'homogenite' with a graded sandy base and a thick unit of homogeneous mud. These authors inferred that the 'homogenites' consist of material from a suspension cloud accompanying the mass movements and/or particles eroded by mass movement-generated seiches in the basins. In Lake Uri, Siegenthaler and Sturm (1991a) found a similar deposit at a stratigraphically higher level. From the geometry of the deposit, these authors concluded that the source area was the river delta of the Muota. However, this deposit could not be correlated to any known earthquake, but found historical reports were found describing an event in AD 1687 with suddenly appearing waves and shoreline inundations on Lake Uri. Therefore, Siegenthaler and Sturm (1991a) proposed that the mass movement was caused by a failure of the Muota delta in AD 1687, which generated large 'surge waves' and caused significant damage around the lake.

\section{Mass-movement terminology}

Various terms have been used to describe mass-movement deposits such as those found in Lake Lucerne, other lacustrine or marine environments, as well as similar deposits in rock outcrops (e.g. Kastens and Cita, 1981; Bouma et al., 1987; Siegenthaler et al., 1987; Chapron et al., 1999; Nakajima and Kanai, 2000; Mulder et al., 2009). Many of these terms have genetic connotations, and apparently similar deposits may have been formed by different processes. For the present study, the terminology of Schnellmann et al. (2005) is used, which is primarily based on the signature of the deposits in reflection seismic profiles. As shown in the case studies below, the different seismic facies correspond to specific lithologies recovered in sediment cores. Although the used terms have genetic connotations as well, they should be understood in a purely descriptive way.

In the following, the term 'megaturbidite' denotes acoustically almost transparent units that are ponded in the deepest parts of a basin. These units represent extraordinarily thick sediment layers with a coarse, graded sandy base that is separated from a much thicker mass of massive, virtually homogeneous mud; they correspond to the 'homogenites' of Siegenthaler et al. (1987). The term 'massflow deposit' is used for acoustically chaotic to semi-transparent bodies that may be separated from neighbouring units by irregular boundaries. 'Massflow deposits', corresponding to the 'slumps' of Siegenthaler et al. (1987) represent sediments of variable composition which generally have an irregular internal structure with deformed to obliterated primary bedding.

\section{HISTORICAL REPORTS: THE EVENTS OF AD 1601 AND AD 1687}

The original 17th Century descriptions of the anomalous waves on Lake Lucerne provide details on the damage and inundations of coastal areas. The first event is coeval with the earthquake in Unterwalden on 18 September 1601, around 1:45 a.m., one of the strongest earthquakes of the last 1000 years in Switzerland (Schwarz-Zanetti et al., 2003; probable intensity VII for Gersau basin and VI for northern part of Lake Uri). A historical account by Renward Cysat (1545-1614), then clerk of the

This article is protected by copyright. All rights reserved. 
city of Lucerne and an eyewitness, reports widespread damage caused by the earthquake (SchwarzZanetti et al., 2003), and additionally depicts the response of the lake after the earthquake. In the distal basins, waves reached a runup of $4 \mathrm{~m}$, and in the city of Lucerne, the outflowing river Reuss periodically changed flow direction over several hours (Schnellmann et al., 2002; Cysat, manuscript, pp. 883-886; Fig. 2).

Information from the proximal basins is sparse and less exact, but the most violent effects were apparently located in the Gersau basin (Cysat, manuscript, pp. 886-887; Fig. 2). People reported that the water in the middle of the lake rose "like a high mountain". Parts of the shore between Ennetbürgen and Beckenried (see Fig. 2 for location names) collapsed into the lake, reportedly killing one person. The plain between Buochs and Ennetbürgen was inundated over a distance of '1000 paces' (ca $750 \mathrm{~m}$ ). In Beckenried, a number of houses were carried into the lake with their inhabitants. Eight people have reportedly been found drowned. Little is reported from other areas around the proximal basins, except for the fact that water levels in Lake Uri oscillated for eight days as a seiche. While a linkage between earthquake and resulting anomalous waves during this first event was obvious for the contemporaries, the second event with anomalous waves was a surprise, because there was no evident cause for the waves, such as a storm or an earthquake.

Three reports, the chronicles of J.L. Bünti (1661-1736; Bünti, manuscript) and J. Billeter (1630-1712; Billeter, manuscript) as well as the diaries of J. Dietrich (1645-1704; Dietrich, manuscript), describe extensive damage around the northern part of Lake Uri on 23 September 1687, around 11:00 p.m. The village of Brunnen was inundated, pieces of wood and debris were deposited in the streets and buildings were damaged. Dietrich (manuscript) mentions two main pulses with damaging backflow. Ships in the harbours and most piers around the lake were destroyed. A part of the shore near the mouth of the river Muota collapsed into the lake. On the opposite shore, between Schillerstein and Treib (Fig. 2), vegetation and soil were stripped off the bare rock up to a height of more than $5 \mathrm{~m}$ ("more than the height of a pike") above normal lake level. In the tavern of Treib, situated on the shore, the basement walls and the pier were destroyed, and the facilities in the first floor were damaged. Effects were less strong in other parts of the lake, but inundations are reported from Flüelen, Buochs and Ennetbürgen, across the basins (Fig. 2). In Lucerne, lake level oscillated with an amplitude of $c a 60 \mathrm{~cm}$.

Using current terminology, both descriptions can be classified as tsunamis, which probably evolved into seiches. Maximum wave runup exceeded $5 \mathrm{~m}$ for both events. Judging from the sparse descriptions, the first event in 1601 was more violent. Although only nine victims are directly mentioned by Cysat (manuscript), the descriptions of houses carried into the lake, missing information from other villages and the predominantly rural area at that time suggest that the actual number of victims may have been higher. No victims are mentioned for the second event and the effects are not described as catastrophic. An assessment of the wave fields and the potential damage of similar events today has to consider that the immediate shores of the lake are more densely inhabited today.

This article is protected by copyright. All rights reserved. 


\section{METHODS AND DATA}

\section{High-resolution bathymetry}

High-resolution bathymetry were collected in the three basins of the study area study area in order to document the lake-floor morphology and topography. In 2007, the Treib basin, the Muota delta and a small part in the north of the Gersau basin were surveyed using a GeoAcoustics GeoSwath Plus interferometric sonar (Kongsberg GeoAcoustics Limited, Great Yarmouth, UK) operating at $125 \mathrm{kHz}$ (details in Hilbe et al., 2011). The resulting datasets have been resampled to a cell size of $2 \mathrm{~m}$. The main parts of the Gersau basin and Lake Uri have been surveyed in March 2012 using a Kongsberg EM2040 multibeam echo sounder (Kongsberg Maritime, Horten, Norway) in $1^{\circ}$ by $1^{\circ}$ beam-width configuration and operated at a frequency of $300 \mathrm{kHz}$. For this campaign, a Kongsberg Seatex MRU5+ motion sensor (Kongsberg Seatex, Trondheim, Norway), a Trimble SPS361 heading sensor (Trimble Navigation Limited, Sunnyvale, CA, USA) and a Leica GX1230 GNSS receiver (Leica Geosystems, Heerbrugg, Switzerland) using the swiposGIS/GEO real-time positioning service (Swiss Federal Office of Topography, Wabern, Switzerland; typical position accuracy 2 to $3 \mathrm{~cm}$ ) were used as auxiliary sensors. Surface sound speed in the water was continuously measured by a Valeport MiniSVS (Valeport Limited, Totnes, UK) sound velocity sensor; vertical sound velocity profiles were recorded at least daily using a Valeport MiniSVP probe. The raw data have been processed in Caris HIPS/SIPS software (Caris, Fredericton, Canada) and merged with the previously acquired data in order to provide a high-resolution digital terrain model with a cell size of $2 \mathrm{~m}$ covering the study area. Analyis of the digital terrain model was performed with standard GIS software.

\section{Reflection seismic profiles}

A grid of single-channel reflection seismic profiles covering the three basins of the study area (Fig. 1) has been recorded in 2008 and 2010 using a $3.5 \mathrm{kHz}$ ORE pinger (Ocean Research Equipment, West Wareham, MA, USA). The data were recorded digitally in SEG-Y format with a flat gain. A bandpass filter ( 2 to $6 \mathrm{kHz}$ ) was applied as the only post-processing step. GPS was used for positioning, providing an accuracy of ca $5 \mathrm{~m}$. Interpretation of the seismic data was conducted using IHS Kingdom Software (IHS Inc., Englewood, CO, USA). For the display of the profiles, water-bottom muting was applied. The estimated water depths shown on the profiles are based on a sound velocity of $1450 \mathrm{~m} / \mathrm{s}$. For the calculation of sediment depth, a mean sound velocity of $1490 \mathrm{~m} / \mathrm{s}$ is used, corresponding to the average of the interval velocities obtained by seismic to core correlation.

\section{Sediment cores}

Eleven Kullenberg-type piston cores (Kelts et al., 1986) with lengths of 5 to $10 \mathrm{~m}$ were obtained in 2011 from the investigated basins (Fig. 1). Gamma ray attenuation bulk density and magnetic susceptibility of the $1 \mathrm{~m}$-long core sections were routinely measured on a Geotek Multi-Sensor Core Logger (Geotek Limited, Daventry, UK). After splitting, the core halves were photographed, described macroscopically and the shear strength of the sediment was measured at intervals of 20 to $50 \mathrm{~cm}$ on the split surfaces of the cores using an Eijkelkamp 14.10 Pocket Vane Tester (Eijkelkamp Agrisearch Equipment, Giesbeek, Netherlands). Additionally, the water content of sediment samples taken in intervals of 30 to $100 \mathrm{~cm}$ was determined by comparing wet and dry weights after drying at $105^{\circ} \mathrm{C}$, This article is protected by copyright. All rights reserved. 
following DIN 18121 (Prinz, 1997). Selected split sections have been scanned with a Siemens Somatom Definition AS medical CT scanner (Siemens Sector Healthcare, Erlangen, Germany) at the University Hospital of Zürich.

Due to high gas content in the sediment, the cores expanded significantly upon retrieval, increasing the length in some parts of the cores, while other parts of the sediment at the section cuts were lost. The length scales for sediment depth given for the composite sections therefore have significant uncertainties. The abundant voids in the cores also caused considerable scatter in the measured bulk density values. Therefore a running average filter with $10 \mathrm{~cm}$ window length has been applied for display.

\section{CASE STUDY 1: GERSAU BASIN}

\section{Lake-floor morphology}

The Gersau basin (Figs 1, 3 and 4), which experienced a destructive tsunami in AD 1601, is east-west elongated, with a flat central basin plain and generally steep lateral slopes in the north and in the south, and is separated from the neighbouring basins by moraine ridges (Hilbe et al., 2011). Prominent features on the lateral slopes are the fan deltas of Gersau and Beckenried (' $a$ ' and ' $b$ ' in Fig. 3); they have characteristic delta-slope morphologies consisting of areas with vertical chutes and ridges, as well as almost featureless areas especially near the present inflows. Slope profiles are linear almost down to the flat basin areas with slope angles typically between $22^{\circ}$ and $28^{\circ}$ and slightly higher $\left(>30^{\circ}\right)$ near the present inflows. The Risleten delta (' $c$ ' in Fig. 3), a small, semi-circular fan delta, has been removed almost completely by gravel mining. West of this delta, a terrace extends over $2 \mathrm{~km}$ ' along the southern margin, in water depths between $140 \mathrm{~m}$ and $195 \mathrm{~m}$ (' $\mathrm{d}$ ' in Fig. 3). It is covered by a thick drape of acoustically layered sediments and separated into several almost flat parts by smooth steps that reflect the topography of the acoustic basement, suggesting that it may be a remnant glacial or bedrock feature.

Morphological signatures of mass movements are widespread in the vicinity of this terrace as well as on the steep lateral slope in the north of the basin (' $e$ ' to ' $h$ ' in Fig. 3), but with less than $0.5 \mathrm{~km}^{2}$ visibly affected, their sizes are limited. In contrast to these only small mass movements, the western part of the basin shows clear morphological signs for large-scale slope instability (Fig. 4). The slopes around this funnel-shaped embayment have generally lower inclinations (typically $<20^{\circ}$ ); they feature a number of scarps with heights of up to $15 \mathrm{~m}$, some of which can be traced over several kilometres. The shallowest scarp typically separates areas with a smooth lake-floor above from areas with more rugged textures below and is interpreted as the headwall of a large slide scar that extends across the embayment down to the deep basin. In very shallow sections less than $c a 10 \mathrm{~m}$ deep, for example, along the southern shore, the scarp may be overprinted and less clearly defined. Parts of the headwall reach the shoreline (for example, ' $a$ ' in Fig. 4). Scarps are preferentially located along zones where the average slope angle increases downslope; they may be straight or crescent-shaped in plan view, depending on the morphology of the substrate (visible, for example, on the 'furrowed' part of the northern slope; ' $b$ ' in Fig. 4). In addition to the headwall, several internal scarps exist,

This article is protected by copyright. All rights reserved. 
most of which border slabs of soft sediment ('buttes') on slope terraces that are apparently in place and may have been overridden by descending masses from above (' $c$ ' in Fig. 4).

These thick packages of soft lacustrine sediments are indicated in the bathymetric data by smooth lake-floor textures (Hilbe et al., 2011). Large areas within the slide scar, however, show rough and irregular surface textures, for instance a region with subdued, east-west trending parallel ridges that covers most of the lower northern slope (' $d$ ' in Fig. 4) or a pattern with elongated grooves parallel to the slope gradient, superposed on an irregular, stepped morphology on the southern slope ('e' in Fig. 4). Such textures may indicate different types of substrate under a thin soft-sediment cover.

The presently active delta of the Engelberger Aa (' $f$ ' in Fig. 4) does not form a large-scale edifice with dominant bedforms down to the basin plain, unlike the other major river deltas in the lake. It builds up a small prograding cone, which is being modified by gravel mining (pits labelled with ' $g$ ' in Fig. 4). Sediment waves as the most prominent bedforms can be observed only in a narrow area along the thalweg in the continuation of the river mouth (' $h$ ' in Fig. 4).

The basin plain is asymmetrical and has its deepest area in the eastern part, as illustrated on a longitudinal seismic profile (Fig. 5). The western part of the basin plain, adjacent to the bay of Buochs and Ennetbürgen, is not completely flat, but shows features with a relief of a few tens of centimetres (' $i$ ' in Fig. 4) as well as on the seismic profile. The most prominent elevation on the basin plain is a ca $1 \mathrm{~km}$ long and ca $300 \mathrm{~m}$ wide tongue-shaped lobe with a hummocky surface and a relief of a few metres, extending from the toe of the northern slope into the basin (' $i$ ' in Fig. 3) below the eastern limit of a long, continuous head scarp on the slope. This lobe is sharply separated from the adjacent basin plain by a well-defined outer bulge.

\section{Subsurface geometry}

A grid of reflection seismic profiles (Fig. 1) documents the geometry of the sediment subsurface. Acoustic penetration reaches a few tens of milliseconds two-way travel time in parts of the deep basin, but decreases quickly in the vicinities of the deltas and in areas that probably contain higher amounts of free gas in the sediment. Most of the sediment fill is acoustically well-layered with laterally continuous, parallel, medium to high-amplitude reflections (Fig. 5). Intercalated between the well-layered sections are sediment bodies with transparent to chaotic seismic facies (five of them are labelled Ga to Ge in Fig. 5); they extend over the entire basin plain and reach thicknesses in the order of metres. This succession reflects the sedimentary environment described above: The layered facies represents the sequences of laminated mud and turbidites, while the chaotic and transparent units are interpreted as larger, episodic mass-movement deposits.

The most voluminous of these units (Gb on Fig. 5), first documented by Siegenthaler et al. (1987), is located a few metres below the lake floor. It has the above-mentioned characteristic geometry consisting of a chaotic to semi-transparent lower subunit and an acoustically almost transparent upper subunit that only locally shows very faint layering. The top surface of the wedge-shaped lower subunit has a pronounced, hummocky morphology and shows reflections of variable amplitudes, including many diffraction hyperbolae. A small number of hummocks are still visible as small-scale

This article is protected by copyright. All rights reserved. 
features on the present-day lake floor (Fig. 5). The upper subunit has a ponding geometry that smoothes out the irregular, hummocky surface of the lower one almost completely and fills the deepest parts of the basin. Using the terminology defined above (after Schnellmann et al., 2005), the lower subunit of $\mathrm{Gb}$ is termed massflow deposit and the upper one is termed megaturbidite.

The base of unit $\mathrm{Gb}$ lies conformably on undisturbed, layered basin sediment in the areas where only the megaturbidite is present. Below the massflow deposit, however, it is located at different stratigraphic levels in different parts of the basin. In the east, where the massflow deposit is thinner and its upper boundary is lower, the base is generally at a higher level than in the western part (Fig. 5). The position of the base is not arbitrary, but there are preferred horizons connected by rather abrupt steps. At the toe of lateral slopes, the base of the chaotic massflow deposit can locally reach lower stratigraphic levels than in surrounding areas, as observed, for example, near the southern basin margin adjacent to the big terrace and in the western part of the basin. In both examples, the lateral slopes above show scarps as signatures of likely source areas of mass movements.

The extent of the massflow deposit of $\mathrm{Gb}$ is controlled by the pre-existing lake-floor topography. Generally decreasing in thickness from east to west, it fills the entire basin plain from the toe of the slopes in the west to the lowermost eastern slope (Fig. 5). In a north-south direction, the deposit covers the entire basin between the steep lateral slopes. Both the base and top surfaces of the massflow deposit are concave upwards. The geometry of the megaturbidite is controlled by the prior topography of the massflow deposit. The megaturbidite is thickest in the deepest parts of the basin and thins quickly towards shallower water depths. In areas more than $c a 10 \mathrm{~m}$ above the deepest point of the basin, it is generally too thin to be resolved on the seismic profiles (Fig. 5).

Thickness maps of the two subunits of $\mathrm{Gb}$, interpolated from the seismic profiles and bathymetry data, illustrate that the thickest part of the massflow deposit (ca $12 \mathrm{~m})$ in the north-west coincides with the tongue-shaped lobe visible in the bathymetry data (Fig. 6; ' $i$ ' in Fig. 3). The massflow deposit of $\mathrm{Gb}$ is also thick along the toe of the slopes in the west, where the base of the chaotic unit locally reaches lower stratigraphic levels. Its main depocentre extends as an arcuate bulge along the northern margin of the basin south-eastwards towards the basin centre. Mapped thicknesses are $c a$ $9 \mathrm{~m}$ along this bulge, generally more than $7 \mathrm{~m}$ in the western part of the deposit, and decrease to less than $4 \mathrm{~m}$ on the eastern lobe (Fig. 6A). The main depocentre of the megaturbidite is in the deepest part of the basin, on top of the eastern lobe of the massflow deposit, with a maximum thickness of $3.3 \mathrm{~m}$. A second small depocentre is situated in a small depression on top of the massflow deposit in the west (Fig. 6B). Volumes calculated from the thickness maps are $42 \times 10^{6} \mathrm{~m}^{3}$ for the massflow deposit and $10 \times 10^{6} \mathrm{~m}^{3}$ for the megaturbidite. The total volume of $52 \times 10^{6} \mathrm{~m}^{3}$ corresponds to more than $1 \%$ of the water volume of the Gersau basin.

Considering its size and architecture, unit $\mathrm{Gb}$ is unique in the imaged part of the subsurface of the Gersau basin. It is identified as a single massflow deposit covered by a large megaturbidite, with the exception of a small, isolated semi-transparent body on the lower eastern slope on the same stratigraphic level (Fig. 5). Other units with similar facies are typically smaller isolated chaotic bodies near basin margins that are often associated with morphological indications of mass movements, and thinner megaturbidites. Although comprising a considerable volume and a maximum thickness of $c a 1 \mathrm{~m}$, the transparent unit Ga can only be tentatively connected to minor chaotic bodies in the This article is protected by copyright. All rights reserved. 
two mentioned areas, below both the northern and the southern lateral slopes. The rather thin transparent unit Gc corresponds to a chaotic body west of Gersau. Unit Gd is semi-transparent, has a thickness of up to $c a 2 \mathrm{~m}$, but no corresponding massflow deposit could be identified clearly. Finally, Ge is a lobe-shaped, chaotic unit located in the basinward continuation of a morphologically wellidentified mass movement on the southern lateral slope (' $f$ ' in Fig. 3; see above). It includes only a very thin transparent unit overlying the chaotic body and another very small chaotic body at the toe of the northern slope west of Gersau.

\section{Sediments}

Four sediment cores (P13 to P16; Figs 1, 5 and 7) have been collected in the Gersau basin. With respect to unit Gb defined above, the core positions cover the thick massflow deposit in the western part of the basin, the deepest part with its thick megaturbidite overlying the thin massflow deposit, and the eastern part, where only the megaturbidite is present. Estimating from the core lengths, the complete massflow deposit was only sampled in core P14, on its thin eastern lobe. The two cores in the main mass (P15 and P16) penetrate only the uppermost metres of the massflow deposit (Fig. 5).

The most common sediment type in the upper metres of all cores is regularly layered, rather monotonous sequences of grey to brown laminated mud ('laminites' of Siegenthaler and Sturm, 1991b; Fig. 7). Typical laminae have thicknesses from less than $1 \mathrm{~mm}$ up to centimetres and mainly consist of clayey silt. Their distinct pattern of colour and lightness variations is consistent within most of the deep basin and allows a visual correlation of cores P13 to P15 almost layer by layer. Turbidites, i.e. graded layers with coarse, sandy bases and light-coloured 'clay caps', occur frequently within the laminated mud (Fig. 8A). Only turbidites or individual laminae with thicknesses of more than $2 \mathrm{~cm}$, as well as thinner layers that can be unambiguously correlated to these thicker layers in other cores, are identified in Fig. 7. Special sediment types intercalated in the laminated mud are accumulations of plant remains and massive sand layers with sharp upper and lower contacts (Fig. 7). The latter are restricted to core P16 and most probably arise from its special position below the delta slope of the main inflow. Laminated mud, intercalated turbidites and special layers are considered as background sediments representing regular sedimentation in the Gersau basin with episodic floods recorded as turbidites (see above; Siegenthaler and Sturm, 1991b).

Embedded within these background sediments are three exceptionally thick turbidites, labelled g1 to g3 in Fig. 7; they are formally distinguished from the 'normal' turbidites based on the criterion that they are at least $10 \mathrm{~cm}$ thick in the deepest core from the basin (i.e. P14). These 'exceptional' turbidites have a special geometry with a maximum thickness in the deepest part of the basin and significantly reduced thickness in the other cores, while 'normal' turbidites are usually thicker in the cores closer to the inflows (P13 or P15; Fig. 7). Lithologically the two types may be similar and cannot necessarily be distinguished visually in a single core, notably near the basin margins where they have similar thicknesses. The exceptional turbidites have sharp lower contacts, coarse bases that may include plant remains (g2 and g3) and a light-coloured, fine-grained 'clay cap', which is usually thin. The main volume is made up of homogeneous, grey mud that shows almost no internal structure (Fig. 8B), justifying the term 'homogenite' used by Siegenthaler et al. (1987). Turbidites g1 and g3

This article is protected by copyright. All rights reserved. 
show multiple grading within the lowermost 10 to $20 \mathrm{~cm}$, i.e. several individual sand layers, the grain size of which decreases upwards and which are separated by finer sediments (Fig. 8C).

While the regularly layered background sediments continue below $\mathrm{g} 3$ in core $\mathrm{P} 13$, all other cores (P14 to P16) show sediments with a composition similar to the background, but mostly deformed to obliterated primary bedding below turbidite g3. The sediments vary from folded and sheared laminated mud (Fig. 8D), with visible but deformed bedding, to mottled and homogeneous mud (Fig. $8 \mathrm{E})$ without clearly visible bedding. Some sections within these disturbed sediments appear to be undeformed and identical to the laminated mud found in undisturbed parts of the cores. Transitions between these categories are gradual and suggest a variable amount of deformation, increasing from apparently undeformed to completely homogenized mud. Especially the intensely deformed parts contain a diversity of exotic materials, such as rounded, gravel-sized pebbles, sand lenses or layers, dispersed shell hash, wood fragments and other plant remains, or individual clasts of mud (Fig. 8E, F and G). In terms of volume, these components are subordinate, but they are widely distributed.

A particular sediment type is found in cores P15 and P16 as a several centimetre thick unit on top of the other deformed lithologies. It consists of $\mathrm{cm}$-sized rounded clasts of mud embedded in a sandy or muddy matrix (Fig. 8H and I) and is identified as mudclast conglomerate in Fig. 7 (cf. Schnellmann et al., 2005; Beck et al., 2007; Van Daele et al., in press). Clasts may show internal lamination and diffuse boundaries against the mud matrix leading to a distinctive, mottled appearance in core photographs. CT scans show clast boundaries more clearly (Fig. 8J).

A ca $2 \mathrm{~m}$ long succession at the base of core P14 can be visually correlated to an equivalent section directly below turbidite g3 in core P13 (Fig. 7). A distinctive yellow layer is visible in both cores and used as index layer. In core P13, this layer is located $c a 25 \mathrm{~cm}$ below turbidite $\mathrm{g} 3$. In core P14, it is present in its supposedly original position in the apparently undisturbed succession at the base of the core, as well as repeatedly within the deformed part, for example, as a fold hinge near its base. A ca $50 \mathrm{~cm}$ thick package of apparently undisturbed laminated mud embedded between deformed parts in core P14 containing the index layer (Fig. 7) can be correlated to corresponding sections in core P13 and further below in core P14. The two occurrences of this package in P14 are equivalent, but not identical, i.e. the relative thicknesses of the laminae are different, suggesting a slightly different deposition area.

The physical properties of the deformed units differ from those of the undeformed sediments. Compared to values expected from the trends for undisturbed sediments, the shear strength of the deformed sediments is generally higher and the water content is slightly lower (Fig. 7).

\section{CASE STUDY 2: LAKE URI AND TREIB BASIN}

\section{Lake-floor morphology}

The two easternmost basins of Lake Lucerne, scene of the second historical tsunami in AD 1687, are located in a similar setting as the Gersau basin (Figs 1 and 3). These basins have steep lateral slopes, flat basin plains and are separated by the prograding delta of the Muota River (Fig. 3).

This article is protected by copyright. All rights reserved. 
Lake Uri, which is elongated north-south, has in many places very steep lateral slopes with fan deltas (only one visible, ' $\mathrm{j}$ ' in Fig. 3) and scree-apron deltas (' $\mathrm{k}$ ' in Fig. 3 ) at the base of the slopes. In several areas, steep cliffs are almost directly adjacent to flat basin sediments. The southern part of the basin is occupied by the long and gently inclined delta slope of the Reuss river delta. The small basin plain of Lake Uri is situated in its northern part (Fig. 9). To the north and south, the basin plain is confined by two elevated areas with pronounced morphologies that indicate large mass-movement deposits.

The deposit to the south of the basin plain is expressed as a hummocky lobe that extends from a lateral fan delta to the centre of the basin (' $a$ ' in Fig. 9). Its front is semi-circular, clearly defined and surrounded at ca $300 \mathrm{~m}$ distance by a faint bulge that offsets the flat basin sediments by 0.5 to $1 \mathrm{~m}$ up towards the lobe. Hummocks have widths of 50 to $100 \mathrm{~m}$ and heights of up to $10 \mathrm{~m}$. The largest feature is a peculiar, up to $20 \mathrm{~m}$ high ridge extending westward over a distance of $c a 500 \mathrm{~m}$. The front of the fan delta on the eastern slope lacks traces of large-scale mass-movement activity related to this lobe. A comparison of the morphology with similar deposits in another part of Lake Lucerne (Hilbe et al., 2011) suggests that this deposit is a large rock-debris cone, which is covered by a considerable post-event sediment drape, as indicated by its smooth small-scale morphology.

The mass-movement deposit north of the basin plain of Lake Uri ('b' in Fig. 9) is indicated by a hummocky surface morphology that covers almost the whole basin width and extends $c a 1.5 \mathrm{~km}$ southward from a small plateau at the toe of the Muota delta. Surface features are smaller than on the rock-debris cone described above, with the largest hummocks (ca $30 \mathrm{~m}$, height up to ca $4 \mathrm{~m}$ ) concentrated below the steep lateral slope in the east. To the south and west, the features become smaller and less pronounced. Towards the delta, they are smoother and smaller ones disappear.

The smaller Treib basin (Figs 1 and 3 ) is characterized by a smooth basin plain in the south-west that rises gently eastwards to the Muota delta and towards the toe of the northern slope, where two small fan deltas ('I' in Fig. 3), as well as minor scree cones with steep fronts and incised chutes (' $\mathrm{m}$ ' in Fig. 3) are observed. Signatures of small-scale mass movements are widespread on the northern and western lateral slopes in the form of lobes with faint relief or slightly hummocky areas near the basin margins, which can be connected to escarpments on the slopes, particularly near the two fan deltas (for example, 'a' in Fig. 10). A striking feature on the basin plain is a ca $800 \mathrm{~m}$ long and $c a 300 \mathrm{~m}$ wide lobe extending from the toe of the Muota delta along the basin axis (' $b$ ' in Fig. 10) that is clearly delineated by an outer bulge with a height of 1 to $2 \mathrm{~m}$. Faintly visible internal bulges running parallel to the outer bulge, with limited lateral continuity, a spacing of 10 to $20 \mathrm{~m}$ and heights of a few decimetres can be identified on its western part (' $c$ ' in Fig. 10). On the eastern part and on the lower slope of the Muota delta, this pattern is replaced by a more irregular, hummocky morphology with stronger relief.

The submerged slope of the Muota delta covers three morphological regions. The western part of the delta facing the Treib basin exhibits relict bedforms and channel-like features (' $d$ ' in Fig. 10). It has smooth surface textures and low slope angles that reach more than $15^{\circ}$ only down to $35 \mathrm{~m}$ water depth. The eastern part of the delta slope is significantly steeper with almost constant slope angles of 20 to $25^{\circ}$ down to $150 \mathrm{~m}$ water depth. Its morphology with small ridges and chutes is similar to the smaller fan deltas (' $\mathrm{e}$ ' in Fig. 10). The more complex central part of the delta with the present river inflow forms an embayment that is also followed by the shoreline (' $f$ ' in Fig. 10). It extends from an This article is protected by copyright. All rights reserved. 
indentation next to the steep front in the east to a fan-like shape with two parallel, ca $5 \mathrm{~m}$ high lateral scarps running from the shallowest areas to the toe of the delta slope in the west (' $\mathrm{g}$ ' in Fig. 10). The central area of the embayment is filled by a depositional fan below the present river mouth (with gravel-mining pits, ' $h$ ' in Fig. 10) and also shows channels with bedforms descending to the deep part of Lake Uri. The lower delta slope beneath the lateral scarps shows a smooth, continuous transition into the hummocky lobe in the Treib basin. The outer bulge of the lobe forms the direct continuation of the upper lateral escarpment on the delta slope, i.e. the western boundary of the embayment (Fig. 10).

\section{Subsurface geometry}

Penetration of the seismic signal in Lake Uri reaches up to $c a 15 \mathrm{~m}$ in the deepest part, but is reduced towards the deltas. Low penetration and abrupt amplitude changes along seismic horizons (Fig. 11) indicate the presence of free gas in the sediment. Seismic data in the Treib basin show very low penetration and were not used. The seismic signatures found in Lake Uri are similar to those of the Gersau basin, and the same terminology is used. The main facies are acoustically well-layered sediments, almost transparent bodies with ponding geometry (megaturbidites) and chaotic to semitransparent bodies (massflow deposits).

Two megaturbidites with faint internal layering can be identified within the uppermost metres of the sediments (units $\mathrm{Ua}$ and $\mathrm{Ub}$ in Fig. 11). While the upper megaturbidite (unit Ua) lacks a corresponding massflow deposit, the lower megaturbidite is associated with a voluminous, chaotic massflow deposit directly underneath (unit Ub; Fig 11). The thickness of megaturbidite Ua reaches ca $1 \mathrm{~m}$ on the basin plain, but decreases quickly in only slightly elevated positions. The megaturbidite of unit $\mathrm{Ub}$ is thicker ( $c a 1.5 \mathrm{~m}$ ) on the basin plain and shows a second focus on the subordinate plain to the south (Fig. 12). North of the basin plain, it has considerable thickness only along the western margin.

The thick massflow deposit of unit Ub covers the entire basin width north of the deepest part towards the toe of the Muota delta. It has a southward dipping to horizontal upper surface with a hummocky morphology that is preserved on the present-day lake floor, because the megaturbidites are thin on most parts of the deposit (Fig. 11). Hence, the deposit can also be identified in the bathymetry data (see above, Fig. 9). In the east-west direction, the massflow deposit is slightly asymmetrical. Its thickness reaches ca $10 \mathrm{~m}$ near the eastern margin, the area with the most pronounced surface morphology, and only 2 to $6 \mathrm{~m}$ along the western margin (Fig. 12). The total volume is ca $11 \times 10^{6} \mathrm{~m}^{3}$.

The massflow deposit has a clearly defined front running east-west beneath the deepest part of the basin and overlies regularly layered strata, forming a characteristic, tapering wedge that is $c a 300 \mathrm{~m}$ wide and ca $2 \mathrm{~m}$ high (Fig. 11). Analogous to the Gersau basin, the base of the massflow deposit is conformable with underlying strata at its tip and jumps to lower horizons in more proximal areas.

The large rock-debris cone south of the basin plain and the surrounding bulge identified in the bathymetry data are covered by a more than $10 \mathrm{~m}$ thick, layered sediment drape and thus

This article is protected by copyright. All rights reserved. 
significantly older than the previously described mass-movement deposits. The seismic units actually responsible for the morphology of this cone cannot be identified.

\section{Sediments}

The four sediment cores from Lake Uri (P5 to P7 and P9, Fig. 13) are located on a transect from the toe of the Muota delta to the basin plain. The cores sample the proximal-marginal part in the west, the central and frontal parts of the massflow deposit of $\mathrm{Ub}$, as well as the basin plain with the thick megaturbidite only (Figs 1 and 11). A transect of cores in the Treib basin (P2 to P4; Fig. 1) covers a proximal position on the lobe on the basin plain (Fig. 10), an intermediate position outside the bulge surrounding this lobe and a distal position in the deepest part of the basin.

The dominant sediment type in both basins is grey to brown laminated mud with intercalated turbidites, similar to the sediments of the Gersau basin (Fig. 14A). All cores from Lake Uri can be visually correlated almost layer by layer, based on the colour pattern of the lamination and intercalated turbidites. Embedded within these background sediments are four exceptionally thick turbidites ( $\geq 10 \mathrm{~cm}$ in core P7). The two thickest turbidites $\mathrm{u} 1$ and $\mathrm{u} 2$ have maximum thicknesses of $95 \mathrm{~cm}$ and $>78 \mathrm{~cm}$ (coring loss) in core P7. Like their analogues in the Gersau basin, they consist of a sandy base in sharp contact with the underlying sediments (Fig. 14B), a massive section consisting of homogeneous mud and a very thin, light-coloured top.

Turbidites $\mathrm{u} 3$ and $\mathrm{u} 4$ are only sampled in core $\mathrm{P} 7,45 \mathrm{~cm}$ below the base of $\mathrm{u} 2$; they are $30 \mathrm{~cm}$ and $34 \mathrm{~cm}$ thick, respectively, and separated by a $6 \mathrm{~cm}$ thin layer of undeformed laminated mud (including a turbidite of $2 \mathrm{~cm}$; Fig. 14C). While $\mathrm{u} 3$ is similar to $\mathrm{u} 1$ and $\mathrm{u} 2$, turbidite $\mathrm{u} 4$ is more complex and contains a second sandy interval with an accumulation of plant remains $10 \mathrm{~cm}$ above its base.

In cores P5, P6 and P9, the turbidite $\mathrm{u} 2$ covers deformed sediments that for the most part differ significantly in their composition from the undeformed sediment types. In core P6, located at the front of the massflow deposit of Ub (see above), u2 overlies a ca $1.3 \mathrm{~m}$ thick package of homogeneous to mottled mud that changes downwards into a $c a 70 \mathrm{~cm}$ long section of deformed laminated mud (Fig. 14D). Visible layers in this lower section can be tentatively correlated with laminae in the undisturbed section separating $\mathrm{u} 2$ and $\mathrm{u} 3$ in core P7. The lowermost $c a 40 \mathrm{~cm}$ of the core consist of homogeneous mud with two sandy intervals. Core P5 from the central part of the massflow deposit of $\mathrm{Ub}$ contains a ca $35 \mathrm{~cm}$ thick accumulation of plant remains consisting mainly of grass and some wood fragments, along with small pebbles and mud clasts (Fig. 14E). This unit is underlain by $\mathrm{ca} 30 \mathrm{~cm}$ of almost homogeneous mud containing up to gravel-sized clasts and then by mud-rich gravel with rounded pebbles at the base of the core (Fig. 14F). In core P9, the corresponding unit contains $c a 2.4 \mathrm{~m}$ of a chaotic mixture of mud, rounded gravel, sand and some plant remains. The lowermost $c a 15 \mathrm{~cm}$ of the core consist of laminated mud without coarse components, probably representing background sediments.

Cores from the Treib basin (not shown, lengths 6.5 to $7.8 \mathrm{~m}$ ) contain mainly monotonous successions of laminated mud with thin turbidites, except for one $20 \mathrm{~cm}$-thick turbidite similar to the exceptional turbidites in the other basins, which is found in core $\mathrm{P} 2$, taken from the deepest part of the basin

This article is protected by copyright. All rights reserved. 
(sediment depth 2.5 to $2.7 \mathrm{~m}$; the corresponding section has been lost in the intermediate core P4). While the two cores from the basin and the intermediate position can be correlated with layer matching, this is not possible for core P3 taken on the lobe. This core shows slightly deformed lamination between $5.0 \mathrm{~m}$ and $5.7 \mathrm{~m}$ sediment depth.

\section{DISCUSSION}

\section{Massflow deposits, megaturbidites and basin sediments}

Both the Gersau basin and Lake Uri each contain one major near-surface mass-movement deposit that is unique in the documented part of the basin fill regarding its volume and extent. The respective mass movements were probably tsunamigenic, considering the volumes involved compared to the basin sizes and estimated velocities (see below; Ward and Day, 2002). The acoustic and sedimentological signatures of these deposits are comparable to other deposits in similar lacustrine (e.g. Chapron et al., 1996) and marine (e.g. Prior et al., 1984) settings. The geometry with two lithologically and acoustically distinct facies has been documented in different perialpine or fjord-type lakes (Schnellmann et al., 2005; Waldmann et al., 2011; Kremer et al., 2012). Lateral and vertical assemblages of 'slumps' or 'debris flow deposits' with 'megaturbidites' have often been attributed to flow transformation between debris flows and turbidity currents along the transport path of the mass movement (e.g. Piper et al., 1999; Nakajima and Kanai, 2000; Talling et al., 2007).

Unusually thick vertical assemblages of a massflow deposit ('debrite') and an overlying megaturbidite, typically resulting from extraordinary mass movements, such as the deposits $\mathrm{Gb}$ and Ub, have been termed 'megabeds' by Haughton et al. (2009). The megaturbidites of Gb and Ub (Figs 5 and 11), corresponding to the thick turbidite layers with sandy bases (g3 and u2, respectively; Figs 7 and 13) are interpreted as deposits from particles put in suspension by the extraordinary mass movements, possibly by a process separating suspended particles transported as concentrated density flows (Mulder and Alexander, 2001) from a plastically deforming mass ('flow partitioning'; Haughton et al., 2009). Sediments from other sources, for example, completely disintegrated, small mass movements, may have contributed to the formation of the sediment cloud. The thickness distribution of the megaturbidite and the clear separation of the two subunits indicate that the megaturbidites have only been deposited after the emplacement of the respective massflow deposits.

For the final deposition of the megaturbidites, seiches generated by the mass movements may have played an important role (Beck et al., 2007). In the confined basins of the study area, such periodic oscillations of the entire water column, or the oscillation of a higher-density bottom layer laden with suspended sediment as an internal seiche, may have moved coarse particles back and forth through traction and kept fine sediments in suspension, possibly for an extended period of days or weeks before deposition (Cita and Aloisi, 2000; Mulder et al., 2009; McHugh et al., 2011). These water movements would explain the strong focusing of the deposit in the deep basin areas with a rather symmetrical thickness distribution, the homogeneous grain sizes in the upper parts of the megaturbidites, and also the multiple grading at the base (Fig. $8 \mathrm{C}$ ). Multiple grading in turbidites can also occur when sediments are transported quasi-coevally from different sources, for example, from This article is protected by copyright. All rights reserved. 
multiple mass movements ('stacked turbidites', e.g. Strasser et al., 2006; Nelson et al., 2012). However, due to the single, dominant sediment source and the considerable number of regularly deposited layers (Fig. 8C), this scenario is considered less likely.

The massflow deposits of units $\mathrm{Gb}$ and $\mathrm{Ub}$, corresponding to the deformed sections in the sediment cores immediately below the respective megaturbidites, were emplaced as coherent and plastically deforming masses (Mulder and Cochonat, 1996). The sediments have been remoulded to variable degree, but a substantial fraction of the deposits shows relics of the original bedding. Remoulding may have led to loss of pore water and compaction of the sediments rather than disintegration and incorporation of ambient water, as evidenced by higher shear strength and lower water content in the deformed units (cf. Prior et al., 1984). Although the large-scale internal structure of the massflow deposits is poorly constrained, the hummocky morphologies of the deposits suggest the presence of only weakly deformed and largely intact blocks of sediment within the transported masses.

Considerable parts of the chaotic units identified as 'massflow deposits' in the seismic data, and also of the deformed sections in the sediment cores, do not originate from the source areas of the mass movements, but represent deformed or entrained basin sediments, which may be lithologically similar (as in the Gersau basin case). This is suggested by the irregular base of the unit in seismic profiles, which cuts into undisturbed, layered sediments, and also by the presence of duplicated sediment packages at the base of the deformed unit that were close to the sediment surface at the time of deposition of the massflow. The incorporation of these slices of sediment probably occurred along weak horizons (for example, thick turbidites, as in Lake Uri; Fig. 13), represented by the different layer-parallel segments at the base of the chaotic unit in the seismic profiles.

The entrainment of pre-existing sediments along most of the movement path in the basin means that hydroplaning of the mass movement (Mohrig et al., 1998; 1999) did not occur. This phenomenon is often observed with fast and sufficiently dense subaqueous mass movements and relies on a thin layer of ambient water trapped between the moving mass and the sediment surface, which significantly reduces basal shear stress and leads to longer runout of the mass movement with only little effect on underlying sediments. Its absence here is notable since prerequisites for hydroplaning, such as a sediment concentration sufficiently high to prevent dissipation of excess pore pressure below the moving mass (Mulder and Alexander, 2001) and a sufficient velocity in excess of $10 \mathrm{~m} / \mathrm{s}$ (estimate based on Ward and Day, 2002; more precisely a sufficient Froude number; Mohrig et al., 1998), seem to be fulfilled. Consequently, the massflow deposits are compact and the overall runout (H/L ratio; Hampton et al., 1996) is relatively modest compared to many other subaqueous mass movements, with rather steep values of $c a 0.03$ (corresponding to $c a 1.5^{\circ}$ average angle) for the Gersau basin and ca 0.06 ( $c a 3.2^{\circ}$ ) for Lake Uri, although slope angles in the distal parts of the deposition area are close to zero or even negative (cf. Figs 5 and 11).

Among possible reasons for the apparently limited mobility of the mass movements are obviously the limited sizes of the basins - the large massflow deposit in the Gersau basin covers almost the complete basin plain - but also the geometry of the studied basins with abrupt changes in slope angle from steep lower slopes $\left(>10^{\circ}\right)$ to the flat basin plains. The locally deep-reaching base of the

This article is protected by copyright. All rights reserved. 
chaotic unit, observed mainly along the lower slope break below slide scars, identifies zones where pre-existing basin sediments have been deformed and dissected into thrust slices by static and dynamic loading by the descending mass movement, down to depths of several metres (Schnellmann et al., 2005). Further propagation of the moving mass on the nearly flat basin plain, over distances of several kilometres, probably deformed and entrained the uppermost layers of the pre-existing basin sediments through basal shear.

Deep-reaching deformation of basin sediments, visible in seismic profiles, often coincides with welldefined topographic bulges ('halos') on the otherwise flat basin plains, shown by the bathymetry data. In fact, these features seem to be characteristic of many mass movements in similar settings (Hilbe et al., 2011); they do not mark the extents of actual mass-movement deposits, but deformation fronts in underlying sediments (Schnellmann et al., 2005). Such features are present in the Gersau basin on a limited scale only ('i' in Fig. 3). However, two remarkable examples exist in the eastern basins, the 'halo' surrounding the rock-debris cone in Lake Uri (Fig. 9) and the lobe along the southern margin of the Treib basin (Fig. 10). For the former, the semi-circular outline and the uniform distance from the debris cone suggest an origin related to basin-sediment deformation, although no seismic evidence is available for this deeply buried deposit. The less subdued morphology of the lobe in the Treib basin with low-amplitude internal bulges suggests a relatively recent age. The sediment core (P3) taken on the lobe reveals apparently undisturbed background sediments without intercalated mass-movement deposits or unambiguous deformation features down to a sediment depth of $c a 7 \mathrm{~m}$. The lobe with its prominent frontal bulge is therefore interpreted as a result of basin-sediment deformation, induced by the load of an assumed massmovement deposit that is poorly constrained but may be responsible for the hummocky morphology on the eastern part of the lobe.

\section{Gersau basin slide, AD 1601}

The morphologically fresh slide scar that occupies most of the western part of the basin is the main source area for the mass-movement deposit $\mathrm{Gb}$. It is the only area in the basin that can deliver the sediment volume required for the deposit, and the geometry of the deposit suggests a source in the west. Here, large parts of the slope have lost their formerly thick soft-sediment drape, as indicated by the up to $15 \mathrm{~m}$ high escarpments and distinct lake-floor textures (Fig. 4). Similar to the neighbouring Vitznau basin (Hilbe et al., 2011), these textures are interpreted as small-scale morphology of the sliding surface of the mass movement, covered by a thin layer of post-event deposits. Texture differences suggest that this surface lies in different types of substrate and may locally be covered by redeposits. Considering the regional geology (Buxtorf et al., 1916), textures may indicate e.g. bedrock (parallel ridges on lower northern slope; 'd' in Fig. 4) or glacial deposits (continuation of onshore deposits on southern slope). In low-gradient areas $\left(<8^{\circ}\right)$, the soft-sediment drape is still present in the form of thick slabs ('buttes') and has obviously remained stable during failure of the steeper sections of the slope (cf. Hilbe et al., 2011).

Determining of the amount of sediment removed by the mass movement based on morphological criteria is subject to large uncertainty. Using an average thickness of $7 \mathrm{~m}$, roughly estimated from escarpment heights, and an area of $3.5 \mathrm{~km}^{2}$, a volume in the order of $25 \times 10^{6} \mathrm{~m}^{3}$, half of the total volume of the deposit, is calculated. Irrespective of the uncertainty, this is less than the volume of

This article is protected by copyright. All rights reserved. 
the mapped deposit, a discrepancy that can be accounted for by the deformed and entrained basin sediments incorporated into the deposits (cf. Moernaut and De Batist, 2011), possible additional smaller source areas on the lateral slopes, and the fact that the delta slope of the Engelberger $A a$ river lies within the slide scar, which complicates the determination of thicknesses of removed sediments and scar boundaries. The Engelberger Aa river delta shows only a small depositional cone at the river mouth and seems to lack a thick sediment cover on most of the lower delta slopes. This absence of a typical delta morphology could be explained by the failure of a significant part of the former delta slope, leaving only relic features visible (Fig. 4). However, because most of the massflow deposit of unit $\mathrm{Gb}$ is fine-grained mud, which occurs both on the basin plain and on non-deltaic lateral slopes, the lateral slopes and entrained basin sediments seem to account for most of the massflow deposits. Nevertheless, the dispersed 'exotic' components found in all cores from proximal to distal position, for example, rounded pebbles and wood fragments, show that a part of the deposits has deltaic and near-shore origins.

Siegenthaler et al. (1987) correlated the two mass-movement deposits $\mathrm{Ga}$ and $\mathrm{Gb}$ with the two strongest historical earthquakes in the area, in AD 1774 and 1601, respectively, based on eventstratigraphic arguments. Current sedimentation rates on the basin plain of the Gersau basin, determined by previous ${ }^{137} \mathrm{Cs}$ dating, are in the order of $5 \mathrm{~mm} /$ year. Using background-sediment depths (without layers $>2 \mathrm{~cm}$, averages of cores $\mathrm{P} 13$ to $\mathrm{P} 15$ ) and a sedimentation rate of $5 \pm$ $1 \mathrm{~mm} /$ year, extrapolated age ranges of AD 1663 to 1779 for Ga and AD 1396 to 1601 for Gb are obtained, matching the dates of the historical earthquakes well if a corrected, back-calculated sedimentation rate of $6 \mathrm{~mm} /$ year is used.

Thus, deposit Gb is interpreted as the result of a sudden collapse of the submerged slopes surrounding the western part of the Gersau basin, triggered by the $\mathrm{M}_{\mathrm{w}} \sim 5.9$ Unterwalden earthquake on 18 September 1601 (Schwarz-Zanetti et al., 2003) and is analogous to the mass movements in the distal basins (Schnellmann et al., 2002, 2005; Hilbe et al., 2011), but even larger in scale. Neither deposits nor source area show clear indications of retrogressive behaviour, such as stacked and overprinted slide scars (Haflidason et al., 2004), implying that failure occurred virtually at once, with mechanisms likely to be similar to those postulated for the distal basins (Strasser et al., 2007; Stegmann et al., 2007). This mass movement generated the historically documented tsunami that devastated the nearby village of Beckenried and inundated the plain between Buochs and Ennetbürgen.

\section{Muota delta collapse, $A D 1687$}

The similar but smaller deposit Ub in Lake Uri shares the same basic architecture with deposit Gb in the Gersau basin. However, different processes are presumably involved. Next to morphological differences, i.e. shorter runout and a more pronounced hummocky surface, the main contrast between the two deposits is the lithological composition. While the two megaturbidites are similar, the massflow deposit of Ub contains coarser-grained sediments compared to both the deposit in the Gersau basin and the background sediments in Lake Uri. The assemblage of muddy gravel, sand and frequent plant remains found especially in cores P5 and P9 is considered as characteristic for the

This article is protected by copyright. All rights reserved. 
whole massflow deposit and a signature of its source area, while the more fine-grained lithology recovered in core P6 from the frontal wedge probably represents deformed basin sediments entrained or pushed forward by the advancing mass movement.

The coarse-grained sediments suggest a deltaic origin, and the morphology and subsurface geometry indicate that the delta slope of the Muota delta is the only plausible sublacustrine source area for the large volume of $\mathrm{Ub}$, since transport direction is southward, and the other basin margins in the area are nearly vertical bedrock slopes. An unambiguous scar with characteristic elements such as headscarps could not be identified on the delta slope. The most likely position of the scar is the concave central part of the delta slope where the currently active depositional cone is located in front of the fixed river mouth. This has already been suspected by Siegenthaler and Sturm (1991a), based on the indented shape of the shoreline. In addition, the stacked escarpments marking the western boundary of this zone, the adjacent hummocky morphology at the toe of the delta and the deformation lobe in the Treib basin, which is directly connected to the presumed scar, form a coherent morphological assemblage indicative of a major mass movement (Fig. 10). However, the rest of the central delta slope shows typical features related to current delta sedimentation that may have overprinted features of a former slide scar.

Although there is no strict linkage between the described morphological signatures on the delta slope and the deposit Ub in Lake Uri, both are expected to result from the same mass movement. Based on a detailed event stratigraphy and ${ }^{137} \mathrm{Cs}$ dating, Ub was dated to AD 1687, the historical tsunami described above (Siegenthaler and Sturm, 1991b). It is thus supposed that the historical tsunami was generated by the collapse of the central part of the Muota delta slope. The mass movement transported deltaic sediments to the base of the delta slope between Lake Uri and the Treib basin, inducing large-scale deformation within the basin-plain sediments of the Treib basin. The main part of the failed mass descended south-eastwards to deeper Lake Uri, forming a massflow deposit with its depocentre near the opposite eastern margin of this basin.

While the earthquake trigger mechanism for the failure in the Gersau basin seems evident, no obvious trigger exists for the Muota delta collapse, which occurred apparently spontaneously. In fact, the historical accounts stress the calm conditions prevailing before the event. From commonly quoted causes and triggers (Hampton et al., 1996; Locat and Lee, 2002; Sultan et al., 2004), earthquakes or storm waves are therefore excluded. Also the role of seepage or water-level changes seems subordinate. Although lake-level has slowly but significantly risen a few metres over the past 1000 years, short-term fluctuations are generally small, as the lake level has been regulated since the 13th Century (Kopp, 1938), and extreme events might have been documented. This leaves oversteepening and rapid sediment accumulation as primary candidates and the influence of free gas from decaying organic matter within the delta sediments as additional possibility.

Other than the axial deltas, the smaller lateral fan deltas show frequent morphological signatures for small mass movements on the steep $\left(>20^{\circ}\right)$ delta slopes, but no indications for large-scale collapses. Their typically coarse-grained sediments are supposed to be at the angle of repose, implying that frequent small-scale failures caused by oversteepening are the normal mode of sedimentation

This article is protected by copyright. All rights reserved. 
(Terzaghi, 1956; Adams and Schlager, 2000). For the Muota delta case, however, the process leading to failure must allow long-term buildup of a large volume of sediment on the delta slope as well as the eventual, sudden failure of this volume. This is hardly possible considering coarse-grained, noncohesive sediments only.

On the present delta slope, coarse sediments are primarily dumped on a depositional cone in the continuation of the river mouth (Fig. 10). Other areas on the slope are covered with a thick drape of finer-grained, silty-clayey sediments. Shifting of the river mouth, as well as only intermittently active distributary channels in a more natural state of the delta, would thus lead to an architecture containing fine-grained drapes and massive, coarse-grained sediment bodies (cf. Postma, 1990). In this succession, burial and rapid loading of a thick, fine-grained layer with limited hydraulic permeability on the delta slope by massive, coarse-grained deposits might lead to buildup of excess pore pressure within the fine-grained layer (Sultan et al., 2004), reducing shear strength and eventually leading to catastrophic failure of the delta. The situation could be aggravated by the artificial fixation of the river mouth, focusing bedload deposition and locally increasing sedimentation rates.

\section{Lateral slope failures versus delta collapses}

The documented tsunamigenic mass movements in Lake Lucerne can be classified based on their source area (deltaic versus non-deltaic) and their trigger mechanisms (seismic versus aseismic). The first 'end member', represented by the failures in the distal basins (e.g. Schnellmann et al., 2005) and mostly applying to the Gersau basin case as well, are earthquake-triggered and spatially extensive failures of a hemipelagic sediment drape on gently inclined lateral slopes. As shown by Strasser et al. (2007), these slopes are stable under static loading conditions and require external load for failure, for example, earthquake shaking. The second 'end member', represented by the Muota delta case, is a large-scale failure of a delta slope with an unknown, aseismic trigger. While the hazard constituted by seismically triggered mass movements - irrespective of the source area - is linked to the earthquake hazard itself and has been quantified at least for lateral slopes (Strasser et al., 2011), the hazard posed by spontaneous failures is less well-known because of few documented major examples (Girardclos et al., 2007) and a missing understanding of the processes leading to failure.

The respective source areas, deltas and spatially extensive lateral slopes with more or less homogeneous, gentle slope angles ( $c a 10$ to $20^{\circ}$ ) are the main potential subaqueous failure areas that can provide the volumes necessary for tsunami generation, in Lake Lucerne as well as in other perialpine lakes and similar environments such as fjords (cf. Schnellmann et al., 2006). Fan deltas are currently not considered as major source areas for tsunamigenic mass movements due to missing evidence for past events. Especially for the described proximal basins, such gentle slopes are rare and most lateral slopes are too steep to allow accumulation of significant amounts of lacustrine sediments. In addition, potential source areas that have failed recently may not host enough sediment required for failure and tsunami generation. Identification and mapping of potential source areas and assessing the amount of sediment currently available, using high-resolution bathymetric

This article is protected by copyright. All rights reserved. 
mapping, seismic profiling, sampling and in situ testing, will thus be an important component of a hazard assessment targeting mass movement-generated tsunamis.

\section{CONCLUSION}

The sediments of Lake Lucerne document a number of subaqueous mass movements. Two particularly severe events in the 17th Century caused damaging tsunamis on the lake. Main signatures of these mass movements, documented in this study based on high-resolution bathymetry, reflection seismic profiles and sediment cores, are huge deposits with maximum thicknesses exceeding $10 \mathrm{~m}$ in the proximal Gersau basin and in Lake Uri, as well as characteristic morphologies in the source areas.

The well-known AD 1601 earthquake in Unterwalden ( $\mathrm{M}_{\mathrm{W}} c a$ 5.9) led to the failure of a several metrethick sediment drape covering the slopes around the western embayment of the Gersau basin, near Buochs and Ennetbürgen (Fig. 3), creating a slide scar with well-defined headwalls encompassing an area of several square kilometres, as well as a deposit covering the entire basin plain. An apparently spontaneous failure of the Muota river delta in AD 1687 created a deposit at the toe of the delta slope in Lake Uri and induced large-scale sediment deformation in the Treib basin. The scar of this mass movement on the delta slope cannot be clearly delimited, as it has most probably been overprinted by ongoing delta sedimentation.

Both mass-movement deposits show a characteristic anatomy with two distinct parts. The lower part, with chaotic seismic facies, consists of deformed sediments with varying composition reflecting the source area and is termed 'massflow deposit'. The upper part, the 'megaturbidite', is acoustically transparent and consists of homogeneous grey mud with a graded, sandy base. These terms have genetic connotations: The lower part was supposedly transported as a coherent mass while the upper part was deposited from suspended particles.

The deposits do not only contain material from the source area, but also a considerable amount of the uppermost, pre-existing sediment layers on the basin plain, which have been deformed or entrained by the mass movement. In addition, basin-plain sediments near the margins have been deformed down to deeper horizons by descending masses from the slopes, leading to morphologically visible bulges marking deformation fronts in underlying sediments. These two types of deformation leading to incorporation of basin sediments in the identified mass-movement deposits imply that reconstructed volumes for these deposits may overestimate the volumes actually transported from the source areas (contributing up to $50 \%$ for the Gersau basin case), thus also affecting calculated wave heights for tsunami models.

The historical examples show that tsunamis generated by subaqueous mass movements occur on perialpine lakes. For earthquake-triggered failures, this awareness is growing with the amount of documented examples and available data. Failures with other causes are only poorly documented and understood, however. A proper assessment of such mass movements as natural hazards will require more extensive data on past events, an understanding of the key geotechnical factors leading

This article is protected by copyright. All rights reserved. 
to failure for different circumstances and an estimation of the consequences, for example, by tsunami modelling.

\section{ACKNOWLEDGEMENTS}

The authors thank the whole teams of Limnogeology at ETH Zürich and Sedimentology at Eawag for invaluable help during fieldwork, especially R. Hofmann for directing coring operations and A.

Zwyssig for help during seismic and multibeam campaigns. I. Brunner and S. Ammann assisted during laboratory work. G. Schwarz-Zanetti provided the hint to and the transcription of the original source of Josef Dietrich. A. Marty performed the CT scans at the University Hospital Zürich. M. Sturm provided unpublished ${ }^{137} \mathrm{Cs}$ data. Acquisition of the EM2040 multibeam echo sounder was supported by Swiss National Science Foundation (project 133790). The bathymetry survey in 2007 was carried out in collaboration with L. Hansen, R. Eilertsen and O. Totland from the Geological Survey of Norway (NGU), supported by the Federal Office for Topography, the Federal Office for the Environment and the Federal Department of Defence, Civil Protection and Sport. Topographic data from swisstopo is reproduced with permission, JA100119. The comments of three reviewers helped to improve an earlier version of the manuscript and are gratefully acknowledged.

\section{REFERENCES}

Adams, E.W and Schlager, W. (2000) Basic types of submarine slope curvature. J. Sed. Res., 70, 814828.

Adams, E.W., Schlager, W. and Anselmetti, F.S. (2001) Morphology and curvature of delta slopes in Swiss lakes: lessons for the interpretation of clinoforms in seismic data. Sedimentology, 48, 661-679.

BAFU (Ed.) (2009) Hydrologisches Jahrbuch der Schweiz 2008. Umwelt-Wissen Nr. 0921. Swiss Federal Office for the Environment, Berne, 578 pp.

Beck, C., Manalt, F., Chapron, E., Van Rensbergen, P. and De Batist, M. (1996) Enhanced seismicity in the early post-glacial period: evidence from the post-Würm sediments of Lake Annecy, northwestern Alps. J. Geodyn., 22, 155-171.

Beck, C., Mercier de Lépinay, B., Schneider, J.-L., Cremer, M., Cagatay, N., Wendenbaum, E., Boutareaud, S., Ménot, G., Schmidt, S., Weber, O., Eris, K., Armijo, R., Meyer, B., Pondard,N., Gutscher, M.-A. and MARMACORE Cruise Party (2007) Late Quaternary co-seismic sedimentation in the Sea of Marmara's deep basins. Sed. Geol., 199, 65-89.

Billeter, J. (manuscript) Pfarrer Jakob Billeter von Aegeri und seine Chronik. Heimat-Klänge, Sonntags-Beilage zu den «Zuger Nachrichten», 3. Jahrgang, Nr. 4, 28. Januar 1923, 15-16.

Bouma, A.H. (1987) Megaturbidite: An acceptable term? Geo-Mar. Lett., 7, 63-67.

Bünti, J.L. (manuscript) Chronik des Johann Laurentz Bünti, Landammann, 1661-1736. Beiträge zur Geschichte Nidwaldens, Heft 34, 1973, pp. 26-27.

This article is protected by copyright. All rights reserved. 
Buxtorf, A., Tobler, A., Niethammer, G., Baumberger, E., Arbenz, P. and Staub, W. (1916) Geologische Vierwaldstättersee-Karte, Spezialkarte No. 66a. Schweizerische Geologische Kommission, 1913-1916.

Chapron, E., Van Rensbergen, P., Beck, C., De Batist, M. and Paillet, A. (1996) Lacustine sedimentary records of brutal events in Lake Le Bourget (Northwestern Alps-Southern Jura). Quaternaire, 7, 155168.

Chapron, E., Beck, C., Pourchet, M. and Deconinck, J.-F. (1999) 1822 earthquake-triggered homogenite in Lake Le Bourget (NW Alps). Terra Nova, 11, 86-92.

Cita, M.B. and Aloisi, G. (2000) Deep-sea tsunami deposits triggered by the explosion of Santorini (3500y BP), eastern Mediterranean. Sed. Geol., 135, 181-203.

Cysat, R. (manuscript) Collectanea Chronica und denkwürdige Sachen pro Chronica Lucernensi et Helvetiae. Erster Band, zweiter Teil. Edited by Josef Schmid, Diebold Schilling. Luzern, 1969, pp. 879888.

Dietrich, J. (manuscript) Diarium von P. Josef Dietrich von Einsiedeln (1645-1704), Bd. 6.

Klosterarchiv Einsiedeln, KAE A.HB.6, p. 202.

Fäh, D., Giardini, D., Kästli, P., Deichmann, N., Gisler, M., Schwarz-Zanetti, G., Alvarez-Rubio, S., Sellami, S., Edwards, B., Allmann, B., Bethmann, F., Wössner, J., Gassner-Stamm, G., Fritsche, S. and Eberhard, D. (2011) ECOS-09 Earthquake Catalogue of Switzerland, Release 2011, Report SED/ECOS/R/001/20110417, Swiss Seismological Service, ETH Zürich, 42 pp.

Finckh, P., Kelts, K. and Lambert, A. (1984) Seismic stratigraphy and bedrock forms in perialpine lakes. Geol. Soc. Am. Bull., 95, 1118-1128.

Fine, I.V., Rabinovich, A.B., Bornhold, B.D., Thompson, R.E. and Kulikov, E.A. (2005) The Grand Banks landslide-generated tsunami of November 18, 1929: preliminary analysis and numerical modeling. Mar. Geol., 215, 45-57.

Gardner, J.V., Mayer, L.A. and Hughs Clarke J.E. (2000) Morphology and processes in Lake Tahoe (California-Nevada). Geol. Soc. Am. Bull., 112, 736-746.

Girardclos, S., Schmidt, O.T., Sturm, M., Ariztegui, D., Pugin, A. and Anselmetti, F.S. (2007) The 1996 AD delta collapse and large turbidite in Lake Brienz. Mar. Geol., 241, 137-154.

Haflidason, H., Sejrup, H.P., Nygård, A., Mienert, J., Bryn, P., Lien, R., Forsberg, C.F., Berg, K. and Masson D. (2004) The Storegga Slide: architecture, geometry and slide development. Mar. Geol., 213, 201-234.

Hampton, M.A., Lee, H.J. and Locat, J. (1996) Submarine landslides. Rev. Geophys., 34, 1, 33-59.

Haughton, P., Davis, C., McCaffrey, W. and Barker, S. (2009) Hybrid sediment gravity flow deposits Classification, origin and significance. Mar. Pet. Geol., 26, 1900-1918.

This article is protected by copyright. All rights reserved. 
Hilbe, M., Anselmetti, F.S., Eilertsen, R.S., Hansen, L. and Wildi, W. (2011) Subaqueous morphology of Lake Lucerne (Central Switzerland): implications for mass movements and glacial history. Swiss J. Geosci., 104, 425-433.

Kastens, K.A. and Cita, M.B. (1981) Tsunami-induced sediment transport in the abyssal Mediterranean Sea. Geol. Soc. Am. Bull., 92, 845-857.

Kelts, K., Briegel, U., Ghilardi, K. and Hsü, K.J. (1986) The limnogeology-ETH coring system. Schweiz. Z. Hydrol., 48, 104-115.

Kopp, J. (1938) Der Einfluss des Krienbaches auf die Gestaltung des Luzernersees und die Hebung des Seespiegels des Vierwaldstättersees. Eclog. Geol. Helv., 31, 376-378.

Kremer, K., Simpson, G. and Girardclos, S. (2012) Giant Lake Geneva tsunami in AD 563. Nature Geosci., 5, 756-757.

Locat, J. and Lee, H.J. (2002) Submarine landslides: advances and challenges. Can. Geotech. J., 39, 193-212.

Masson, D.G., Harbitz, C.B., Wynn, R.B., Pedersen, G. and Løvholt, F. (2006) Submarine landslides: processes, triggers and hazard prediction. Phil. Trans. Roy. Soc. London A, 364, 2009-2039.

McAdoo, B. and Watts, P. (2004) Tsunami hazard from submarine landslides on the Oregon continental slope. Mar. Geol., 203, 235-245.

McHugh, C.M., Seeber, L., Braudy, N., Cormier, M.-H., Davis, M.B., Diebold, J.B., Dieudonne, N., Douilly, R., Gulick, S.P.S., Hornbach, M.J., Johnson III, H.E., Ryan Mishkin, K., Sorlien, C.C., Steckler, M.S., Symithe, S.J. and Templeton, J. (2011) Offshore sedimentary effects of the 12 January 2010 Haiti earthquake. Geology, 39, 723-726.

McPherson, J.G., Shanmugam, G. and Moiola, R.J. (1987) Fan-deltas and braid deltas: Varieties of coarse-grained deltas. Geol. Soc. Am. Bull., 99, 331-340.

Moernaut, J. and De Batist, M. (2011) Frontal emplacement and mobility of sublacustrine landslides: Results from morphometric and seismostratigraphic analysis. Mar. Geol., 285, 29-45.

Mohrig, D., Whipple, K.X., Hondzo, M., Ellis, C. and Parker, G. (1998) Hydroplaning of subaqueous debris flows. Geol. Soc. Am. Bull., 110, 387-394.

Mohrig, D., Elverhoi, A. and Parker, G. (1999) Experiments on the relative mobility of muddy subaqueous and subaerial debris flows, and their capacity to remobilize antecedent deposits. Mar. Geol., 154, 117-129.

Mulder, T. and Cochonat, P. (1996) Classification of offshore mass movements. J. Sed. Res., 66, 4357.

Mulder, T. and Alexander, J. (2001) The physical character of subaqueous sedimentary density flows and their deposits. Sedimentology, 48, 269-299.

This article is protected by copyright. All rights reserved. 
Mulder, T., Zaragosi, S., Razin, P., Grelaud, C., Lanfumey, V. and Bavoil, F. (2009) A new conceptual model for the deposition of homogenite: Application to a cretaceous megaturbidite of the western Pyrenees (Basque region, SW France). Sed. Geol., 222, 263-273.

Murty, T.S. (2003) Tsunami wave height dependence on landslide volume. Pure Appl. Geophys., 160, 2147-2153.

Nakajima, T. and Kanai, Y. (2000) Sedimentary features of seismoturbidites triggered by the 1983 and older historical earthquakes in the eastern margin of the Japan Sea. Sed. Geol., 135, 1-19.

Nelson, C.H., Gutiérrez Pastor, J., Goldfinger, C. and Escutia, C. (2012) Great earthquakes along Western United States continental margin: implications for hazards, stratigraphy and turbidite lithology. Nat. Hazards Earth Syst. Sci., 12, 3191-3208.

Nemec, W. (1990) Deltas - remarks on terminology and classification. In: Coarse-Grained Deltas (Eds. A. Colella and D.B. Prior), Int. Assoc. Sedimentol. Spec. Publ., 10, 3-12.

Piper, D.J.W., Cochonat, P. and Morrison, M.L. (1999) The sequence of events around the epicentre of the 1929 Grand Banks earthquake: initiation of debris flows and turbiditiy currents inferred from sidescan sonar. Sedimentology, 46, 79-97.

Postma, G. (1990) Depositional architecture and facies of river and fan deltas: a synthesis. In: CoarseGrained Deltas (Eds. A. Colella and D.B. Prior). Int. Assoc. Sedimentol. Spec. Publ., 10, 13-27.

Prinz, H. (1997) Abriss der Ingenieurgeologie. Enke, Stuttgart, 546 pp.

Prior, D.B., Bornhold, B.D. and Johns, M.W. (1984) Depositional characteristics of a submarine debris flow. J. Geol., 92, 707-727.

Schnellmann, M., Anselmetti, F.S., Giardini, D., McKenzie, J.A. and Ward, S.N. (2002) Prehistoric earthquake history revealed by lacustrine slump deposits. Geology, 30, 1131-1134.

Schnellmann, M., Anselmetti, F.S., Giardini, D. and McKenzie, J.A. (2005) Mass movement-induced fold-and-thrust belt structures in unconsolidated sediments in Lake Lucerne (Switzerland).

Sedimentology, 52, 271-289.

Schnellmann, M., Anselmetti, F.S., Giardini, D. and McKenzie, J.A. (2006) 15,000 Years of massmovement history in Lake Lucerne: Implications for seismic and tsunami hazards. Eclogae Geol. Helv., 99, 409-428.

Schwarz-Zanetti, G., Deichmann, N., Fäh, D., Giardini, D., Jimenez, M.-J., Masciadri, V., Schibler, R. and Schnellmann, M. (2003) The earthquake in Unterwalden on September 18, 1601: A historicocritical macroseismic evaluation. Eclogae Geol. Helv., 96, 441-450.

Siegenthaler, C. and Sturm, M. (1991a) Slump induced surges and sediment transport in Lake Uri, Switzerland. Verh. Int. Ver. Theor. Angew. Limnol., 24, 955-958.

Siegenthaler, C. and Sturm, M. (1991b) Die Häufigkeit von Ablagerungen extremer ReussHochwasser. Die Sedimentationsgeschichte im Urnersee seit dem Mittelalter. Mitt. Bundesamt $f$. Wasserwirtschaft, 4, 127-139.

This article is protected by copyright. All rights reserved. 
Siegenthaler, C., Finger, W., Kelts, K. and Wang, S. (1987) Earthquake and seiche deposits in Lake Lucerne, Switzerland. Eclogae Geol. Helv. , 80, 241-260.

Stegmann, S., Strasser, M., Anselmetti, F. and Kopf, A. (2007) Geotechnical in situ characterization of subaquatic slopes: The role of pore pressure transients versus frictional strength in landslide initiation. Geophys. Res. Lett., 34, L07607.

Strasser, M., Anselmetti, F.S., Fäh, D., Giardini, D. and Schnellmann, M. (2006) Magnitudes and source areas of large prehistoric northern Alpine earthquakes revealed by slope failures in lakes. Geology, 34, 1005-1008.

Strasser, M., Stegmann, S., Bussmann, F., Anselmetti, F.S., Rick, B. and Kopf, A. (2007) Quantifying subaqueous slope stability during seismic shaking: Lake Lucerne as model for ocean margins. Mar. Geol., 240, 77-97.

Strasser, M., Hilbe, M. and Anselmetti, F.S. (2011) Mapping basin-wide subaquatic slope failure susceptibility as a tool to assess regional seismic and tsunami hazards. Mar. Geophys. Res., 32, 331347.

Sultan, N., Cochonat, P., Canals, M., Cattaneo, A., Dennielou, B., Haflidason, H., Laberg, J.S., Long, D., Mienert, J., Trincardi, F., Urgeles, F., Vorren, T.O. and Wilson, C. (2004) Triggering mechanisms of slope instability processes and sediment failures on continental margins: a geotechnical approach. Mar. Geol., 213, 291-321.

Talling, P.J., Wynn, R.B., Masson, D.G., Frenz, M., Cronin, B.T., Schiebel, R., Akhmetzhanov, A.M., Dallmeier-Tiessen, S., Benetti, S., Weaver, P.P.E., Georgiopoulou, A., Zühlsdorff, C. and Amy, L.A. (2007) Onset of submarine debris flow deposition far from original giant landslide. Nature, 450, 541544.

Tappin, D.R., Watts, P. and Grilli, S.T. (2008) The Papua New Guinea tsunami of 17 July 1998: anatomy of a catastrophic event. Nat. Hazards Earth Syst. Sci., 8, 243-266.

Terzaghi, K. (1956) Varieties of Submarine Slope Failures. Proceedings of the $8^{\text {th }}$ Texas Conference on Soil Mechanics and Foundation Engineering, 41 pp.

Thevenon, F. and Anselmetti, F.S. (2007) Charcoal and fly-ash particles from Lake Lucerne sediments (Central Switzerland) characterized by image analysis: anthropologic, stratigraphic and environmental implications. Quat. Sci. Rev., 26, 2631-2643.

Van Daele, M., Cnudde, V., Duyck, P., Pino, M., Urrutia, R. and De Batist, M. (in press) Multidirectional, synchronously-triggered seismo-turbidites and debrites revealed by X-ray computed topography (CT). Sedimentology, doi:10.1111/sed.12070.

Waldmann, N., Anselmetti, F.S., Ariztegui, D., Austin, J.A., Pirouz, M., Moy, C.M. and Dunbar, R. (2011) Holocene mass-wasting events in Lago Fagnano, Tierra del Fuego ( $\left.54^{\circ} \mathrm{S}\right)$ : implications for paleoseismicity of the Magallanes-Fagnano transform fault. Basin Res., 23, 171-190.

Ward, S.N. (2001) Landslide tsunami. J. Geophys. Res., 106, 11201-11215.

This article is protected by copyright. All rights reserved. 
Ward, S.N. and Day, S. (2002) Suboceanic landslides. In: 2002 Yearbook of Science and Technology, pp. 349-352. McGraw-Hill, New York.

\section{FIGURES}

Fig. 1: (A) Lake Lucerne and surrounding area on the northern margin of the Swiss Alps, Central Europe, with four main tributaries and outflow, numbers indicating mean discharge and catchment areas (from BAFU, 2009). Three investigated basins are highlighted in yellow; the main study area is outlined with a red frame. Contour interval within the lake is $20 \mathrm{~m}$; shaded relief is generated from swissalti3D digital terrain model. Geographical data by swisstopo, reproduced with permission JA100119. (B) Overview of available datasets in the study area. High-resolution bathymetry data is available for the whole study area, except for a few near-shore areas (Fig. 3). Black dots show positions of piston cores, blue lines show the grid of seismic profiles; highlighted red profiles are presented in the figures. Red boxes indicate positions of the detailed bathymetric maps shown as figures.

Fig. 2: Compilation of observed phenomena related to tsunamis for the earthquake of AD 1601 (blue) and the event of AD 1687 (red), as described in the historical accounts. This dataset is certainly sparse and includes only a small number of the actual effects. Note that for 1601, large subaqueous mass movements probably responsible for the phenomena also occurred outside the main study area.

Fig. 3: Bathymetric map of the study area including Gersau basin, Treib basin and the northern part of Lake Uri (shaded relief, colours according to depth). Features discussed in the text are labelled: ' $a$ ' Gersau fan delta; ' $b$ ' Beckenried fan delta; ' $c$ ' Risleten delta; ' $d$ ' submerged terrace; ' $e$ ' traces of shallow sediment instability near gravel-mining site on Risleten delta; ' $f$ ' excavated zone and hummocky deposit of medium-sized mass movement; ' $\mathrm{g}$ ' and ' $\mathrm{h}$ ' escarpments on steep northern lateral slope; ' $i$ ' bulges on basin plain; ' $j$ ' Sisikon fan delta; ' $k$ ' and ' $m$ ' scree-apron deltas; ' 1 ' fan deltas. Submerged moraine ridges separating the basins are numbered: (I) Nase moraine; (II) Chindli moraine (see Hilbe et al., 2011).

Fig. 4: Bathymetric map of the western part of the Gersau basin showing mass movement-related features (detail of Fig. 3). Prominent scarps, including a headwall delimiting the large slide scar, are indicated with thin white lines; scarps on the slope of the Engelberger Aa delta are questionable. Features discussed in the text are labelled: ' $a$ ' headwall reaching shoreline; ' $b$ ' headwall on 'furrowed' substratum morphology; ' $c$ ' intact soft sediment slabs with smooth textures; ' $d$ ' and ' $e$ ' different lake-floor textures within the slide scar; ' $f$ ' prograding delta cone; ' $g$ ' gravel-mining pits; ' $h$ ' sediment waves; ' $i$ ' basin plain morphology.

Fig. 5: Longitudinal reflection seismic profile along the Gersau basin, see Fig. 1 for location. Seismic units discussed in the text are outlined (top - broken line; base - solid line) and labelled Ga to Ge. The two subunits of Gb ('massflow deposit' with chaotic, semi-transparent facies; 'megaturbidite' with transparent facies) are separated by a dotted line. Sediment cores (see Fig. 7) are indicated by black vertical lines (some positions have been projected onto the profile; depths of units are thus inconsistent).

This article is protected by copyright. All rights reserved. 
Fig. 6: Thickness maps of (A) massflow deposit (chaotic facies; lower subunit) and (B) megaturbidite (transparent facies; upper subunit) of seismic unit Gb. Apparently the thickest zones of massflow deposit below slopes in the west coincide with a locally deep-reaching base indicating deformation of basin sediments. Actual depocentre of massflow deposit forms an arcuate bulge near the northern basin margin. The megaturbidite is restricted to the deepest part of the basin, its thickness is largest in depressions created by the underlying massflow deposit.

Fig. 7: Stratigraphic logs of piston cores taken in the Gersau basin, with bulk density, magnetic susceptibility, water content and shear strength values. Special layers within laminated mud (massive sand and plant remains) are only identified if they are $>2 \mathrm{~cm}$ or $>1 \mathrm{~cm}$ thick, respectively. Core correlations are shown for turbidites and are only possible for P13 to P15 above g3. Rectangles with capital letters show the positions of photographs in Fig. 8.

Fig. 8: Photographs of split core surfaces and CT scan sections parallel to split surfaces (F) and (J), showing typical lithologies from Gersau basin (numbers indicating composite depth): (A) laminated mud with turbidite; (B) and (C) homogeneous part and multiply graded base of exceptionally thick turbidite, respectively; (D) folded laminated mud; (E) and (F) homogeneous mud with coarse fragments; $(G)$ folded to mottled mud with sand lens and mud clast; $(H)$ mudclast conglomerate with sandy matrix; (I) and (J) mudclast conglomerate with muddy matrix.

Fig. 9: Bathymetric map of the northern part of Lake Uri, showing the hummocky surface indicating a rockfall deposit (?) with 'halo' at ca 300 m distance 'a' and different hummocky morphology of a mass-movement deposit at the toe of Muota delta ' $b$ '. Note the limited range of the colour scale; see Fig. 1 for location.

Fig. 10: Bathymetric map of Muota delta and the easternmost part of Treib basin. Features discussed in the text are labelled: ' $a$ ' small-scale mass movement with escarpment and hummocky deposit; ' $b$ ' lobe on basin plain with frontal bulge; ' $c$ ' internal bulges on lobe; ' $d$ ' bedforms on delta slope; ' $e$ ' steep eastern part delta slope with chutes; ' $f$ ' indented central part of delta slope; ' $g$ ' lateral scarps; ' $h$ ' gravel-mining pits. Note the limited range of the colour scale; see Fig. 1 for extent.

Fig. 11: Reflection seismic profile along the northern part of Lake Uri. See Fig. 1 for location. Seismic units discussed in the text are outlined (top - broken line; base - solid line) and labelled (Ua and Ub). Deeper-lying isolated chaotic bodies at the toe of lateral delta are indicated with broken lines. The top of lower part of unit Ub ('massflow deposit') is outlined with a dotted line. Vertical black lines show the positions of sediment cores (core P9 projected).

Fig. 12: Thickness maps of (A) massflow deposit (lower subunit) and (B) megaturbidite (upper subunit) of seismic unit Ub. Note the concentration of the massflow deposit near the eastern basin margin and consequently thicker megaturbidite near western margin, as well as the second depocentre of the megaturbidite on a slightly elevated plateau south of the main depocentre.

Fig. 13: Stratigraphic logs of piston cores from Lake Uri, with bulk density, magnetic susceptibility, water content and shear strength values. Special layers within laminated mud (massive sand, plant remains) are only identified if they are $>2 \mathrm{~cm}$ or $>1 \mathrm{~cm}$ thick, respectively. Core correlations are shown for turbidites and are possible for all cores above u2. Rectangles with capital letters show positions of photographs in Fig. 14.

This article is protected by copyright. All rights reserved. 
Fig. 14: Photographs of split core surfaces showing typical lithologies from Lake Uri (numbers indicating composite depth): (A) laminated mud with turbidite (background); (B) erosive, sandy base of thick turbidite $u 2$; (C) background sediments separating u3 and u4; (D) deformed laminated mud from deformed sediments in frontal wedge of $\mathrm{Ub}$; $(\mathrm{E})$ accumulation of muddy plant remains; $(\mathrm{F})$ muddy gravel with rounded pebbles.
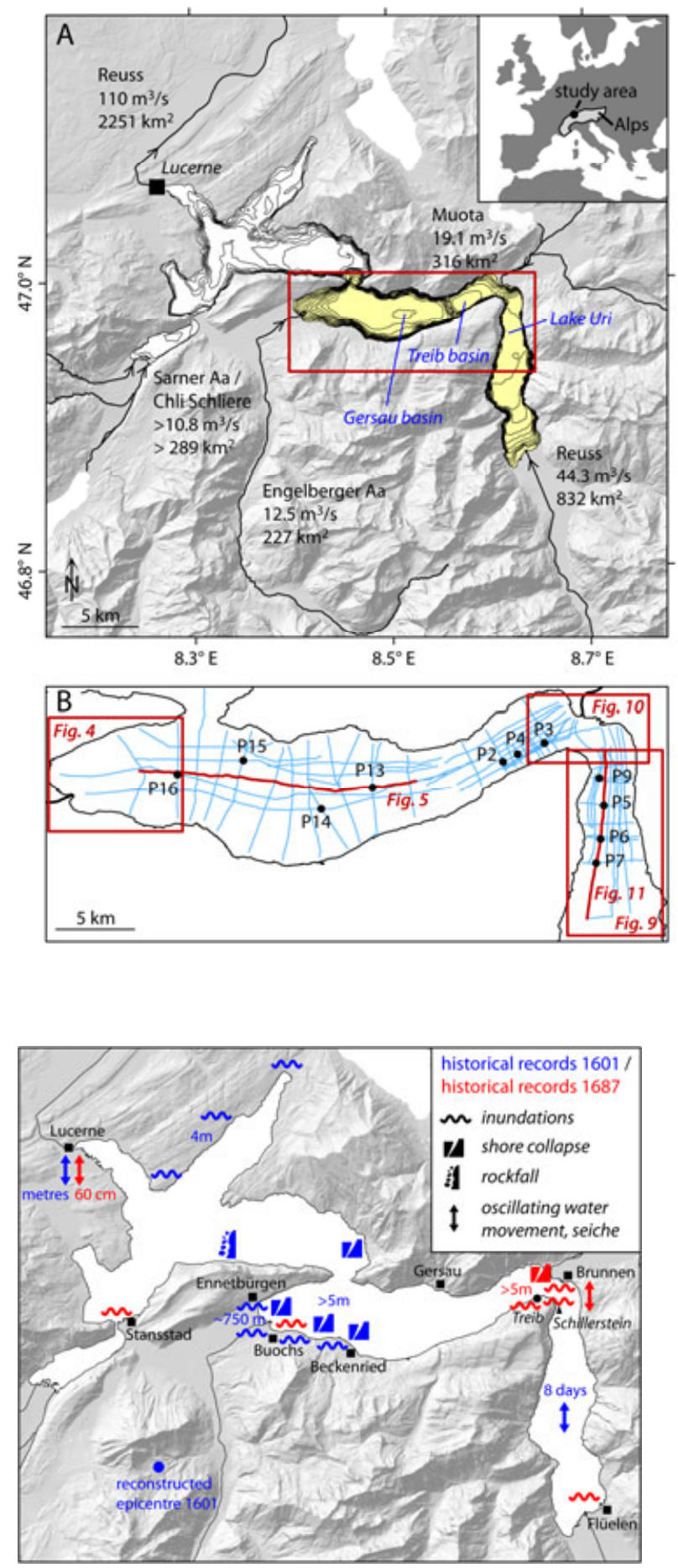

This article is protected by copyright. All rights reserved. 

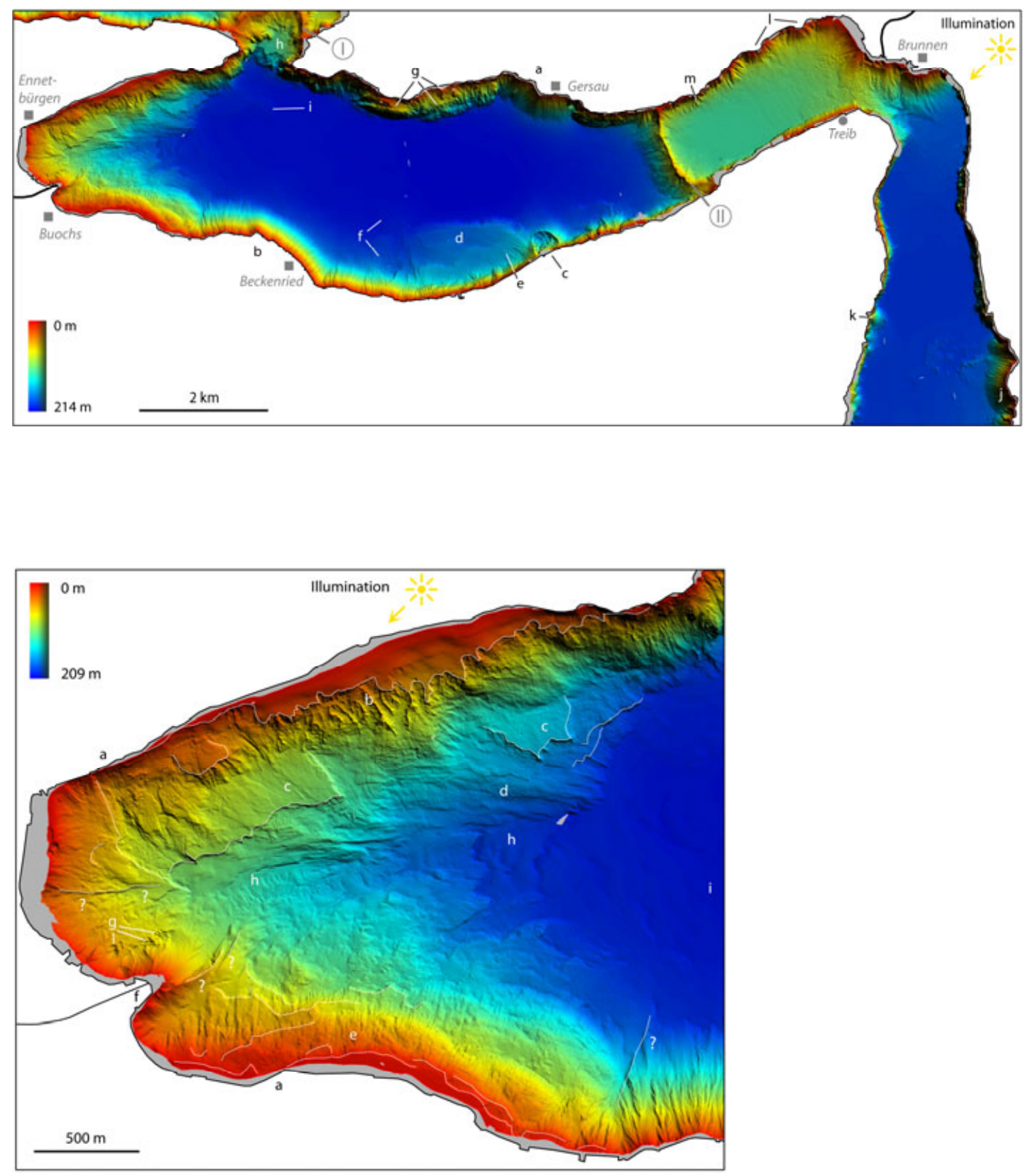

This article is protected by copyright. All rights reserved. 

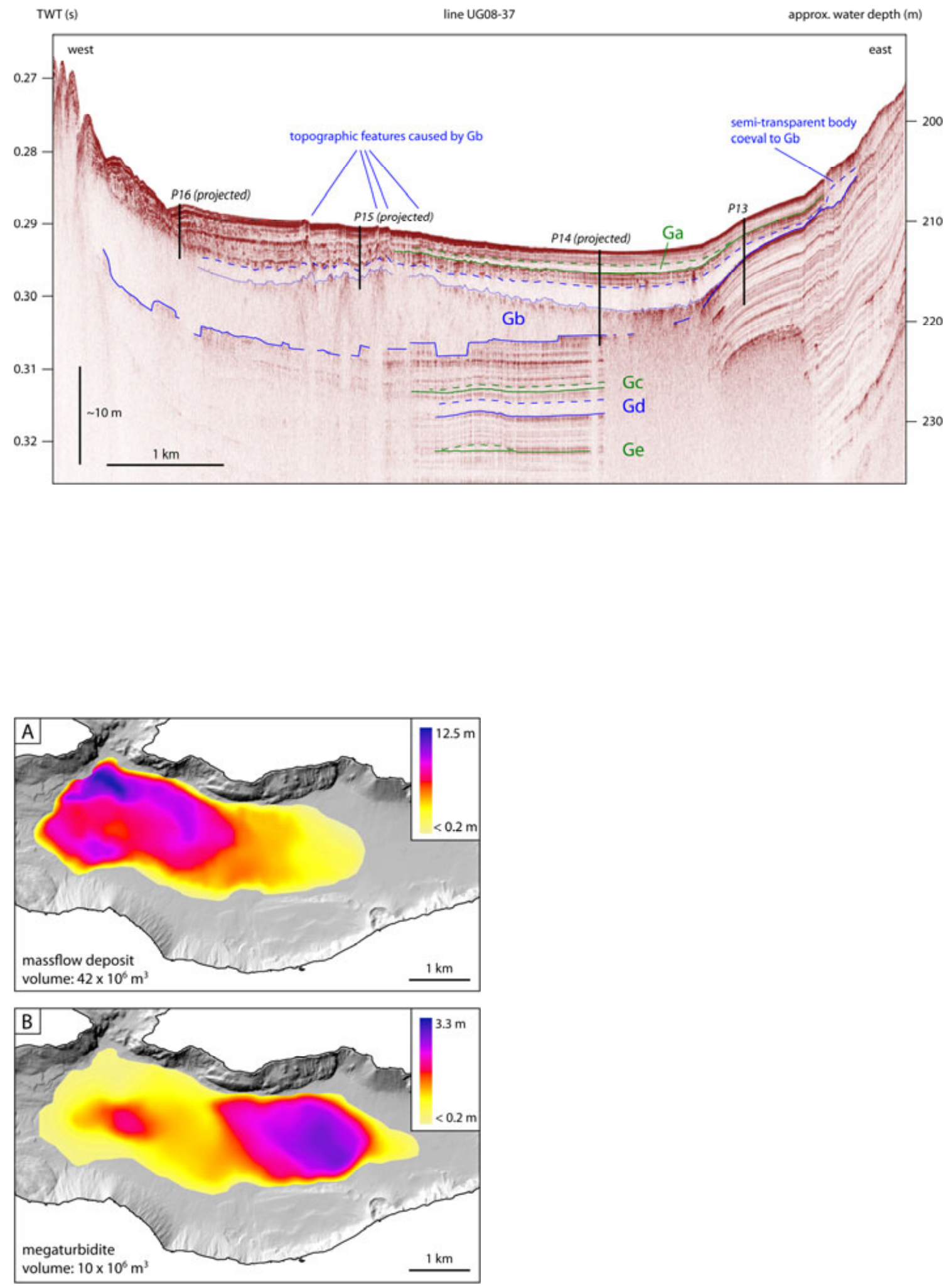

This article is protected by copyright. All rights reserved. 

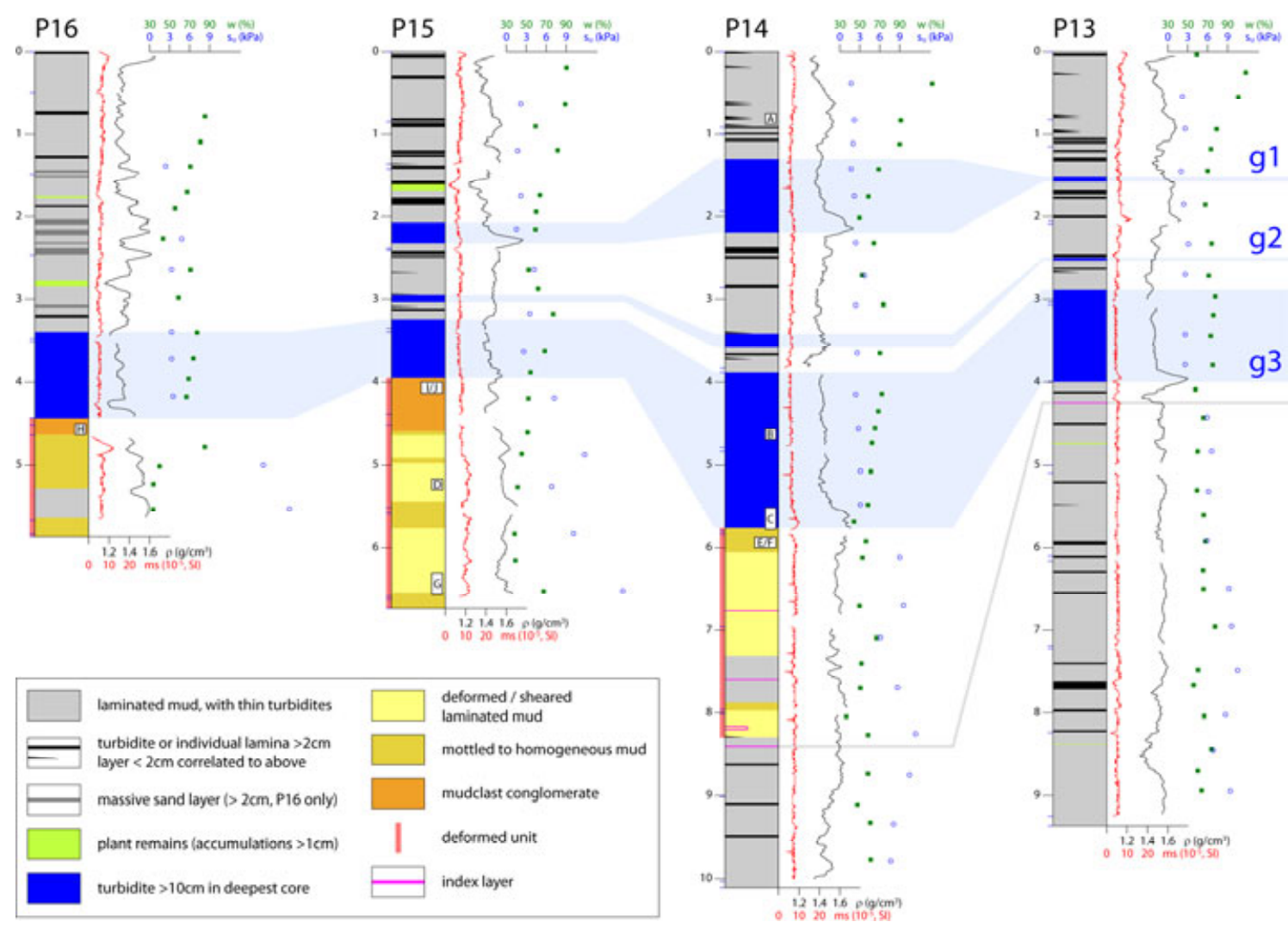

This article is protected by copyright. All rights reserved. 

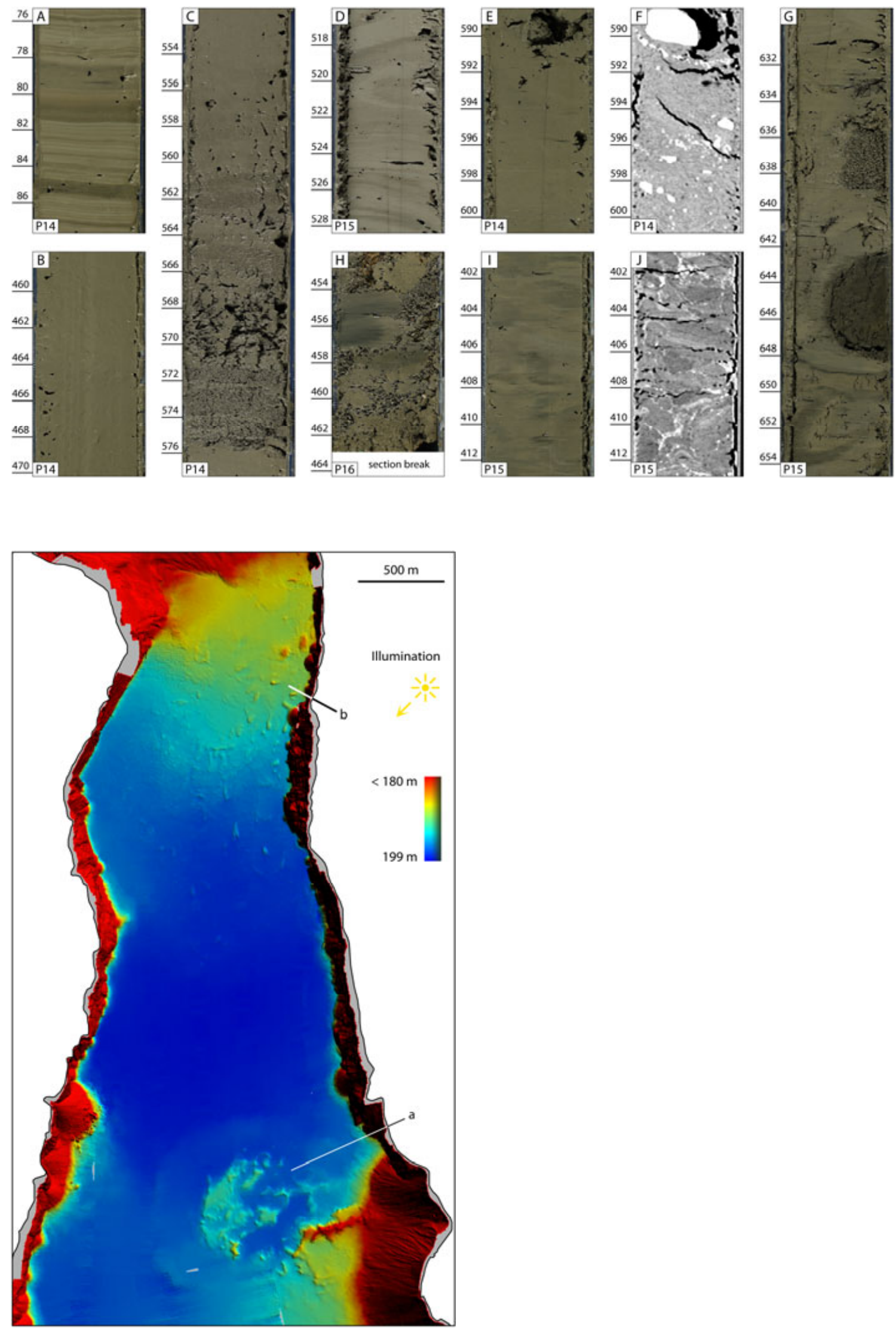

This article is protected by copyright. All rights reserved. 

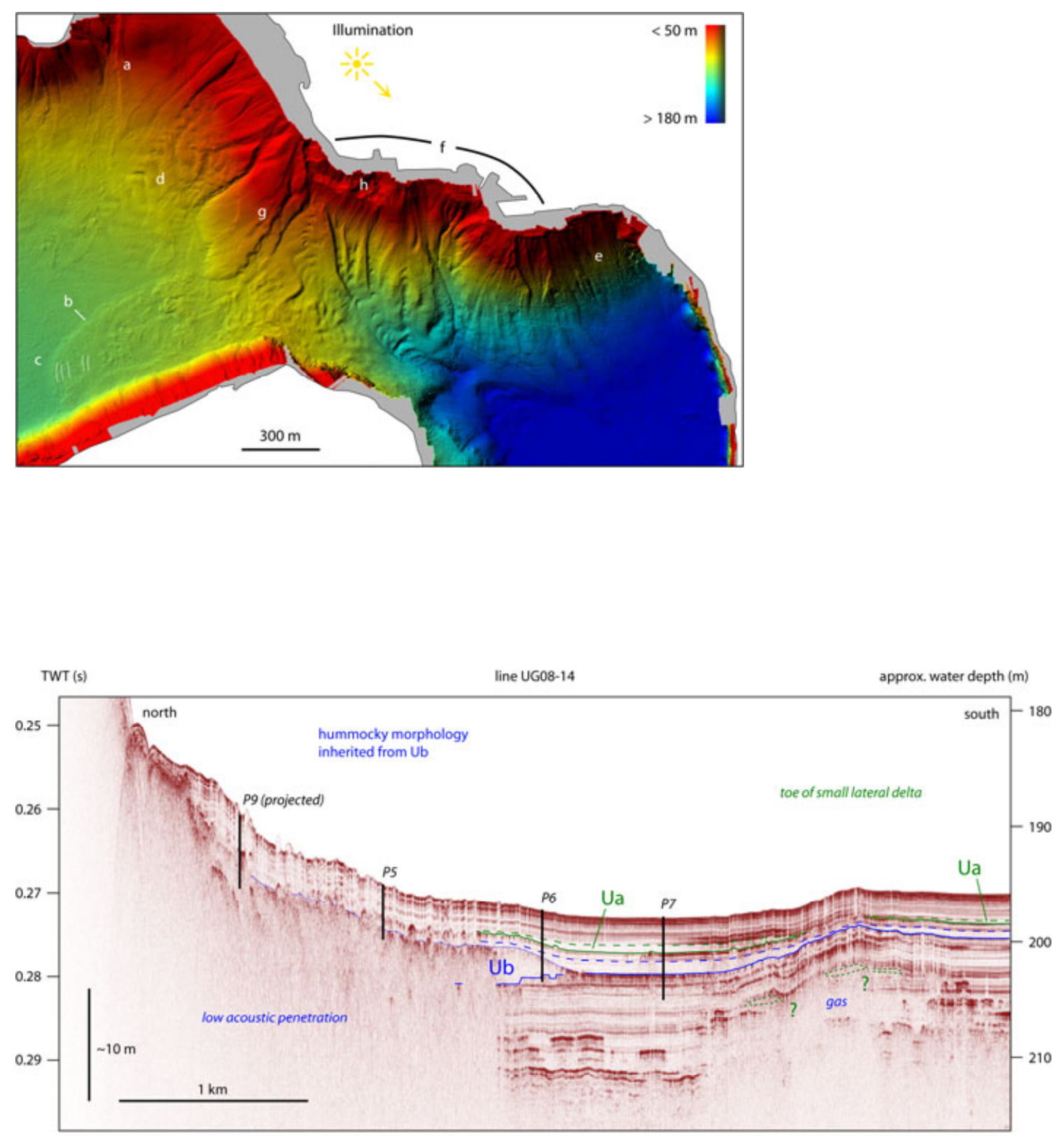

This article is protected by copyright. All rights reserved. 

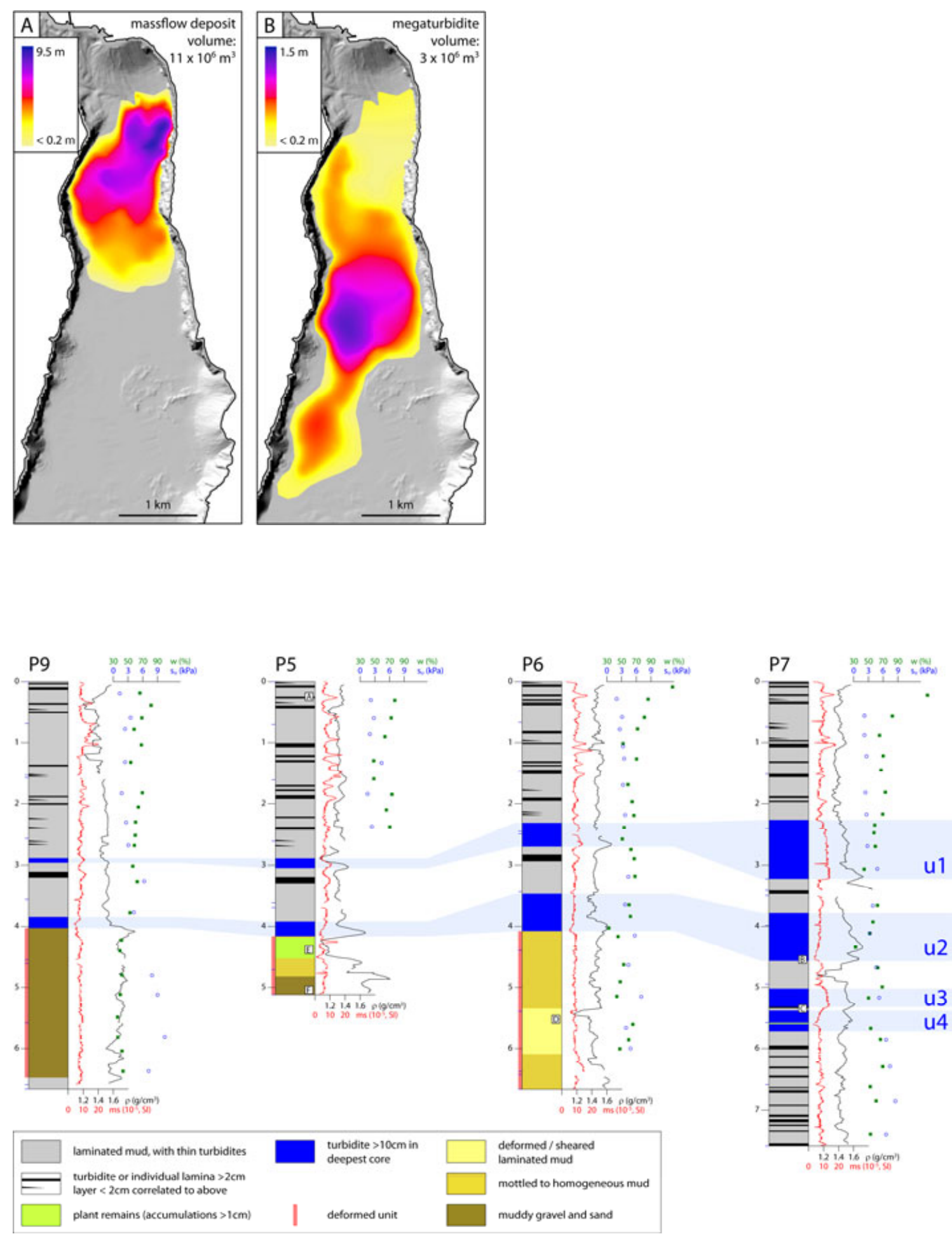

This article is protected by copyright. All rights reserved. 

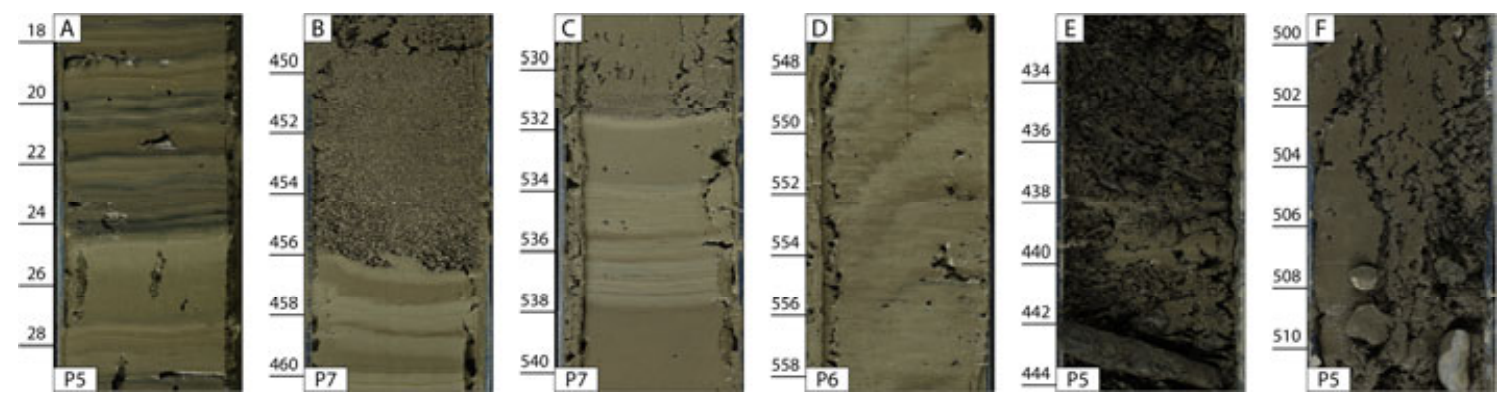

This article is protected by copyright. All rights reserved. 